Boise State University

ScholarWorks

Early and Special Education Faculty

Publications and Presentations

Department of Early and Special Education

$11-19-2021$

\title{
Early Math Interventions in Informal Learning Settings Coding Protocol
}

Gena Nelson

Boise State University

Hannah Carter

Boise State University

Peter Boedeker

Boise State University

Publication Information

Nelson, Gena; Carter, Hannah; and Boedeker, Peter. (2021). "Early Math Interventions in Informal Learning Settings Coding Protocol". Early and Special Education Faculty Publications and Presentations, 141.

https://doi.org/10.18122/sped141.boisestate

This material is based upon work supported by the National Science Foundation under Grant DUE- 2000292. 


\title{
Early Math Interventions in Informal Learning Settings Coding Protocol
}

\author{
Gena Nelson \\ Department of Early \& Special \\ Education \\ Boise State University
}

\author{
Hannah Carter \\ Department of Literacy, Language and \\ Culture \\ Boise State University
}

\author{
Peter Boedeker \\ Department of Curriculum, Instruction \\ and Foundational Studies \\ Boise State University
}

\begin{abstract}
The purpose of document is to provide readers with the coding protocol that authors used to code experimental and quasi-experimental early mathematics intervention studies conducted in informal learning environments. The studies were conducted in homes and in museums with caregivers as intervention agents and included children between the ages of 3,0 and 8,11 years. The coding protocol includes more than 200 variables related to basic study information, participant sample size and demographics, methodological information, intervention information, mathematics content information, the control/comparison condition, outcome measures, and results and effect sizes. The coding protocol was developed for the purpose of conducting a meta-analysis; results of the meta-analysis is pending. The data set associated with this coding protocol will be available to the public at the conclusion of the grant (early 2024).
\end{abstract}

Keywords: early math, intervention, home learning environment, home mathematics environment, meta-analysis, coding protocol

Funding Statement: This material is based upon work supported by the National Science Foundation under Grant DUE- 2000292. 
This coding protocol includes variables in the following categories:

- Basic Study Information (p. 1)

- Participant Sample Size and Demographics (p. 3)

- Methodological Information (p. 20)

- Intervention Information (p. 29)

- Mathematics Content Information (p. 40)

- The Control/Comparison Condition (p. 49)

- Outcome Measures (p. 53)

- Results and Effect Sizes (p. 63)

\section{Coding Protocol: Basic Study Information}

\begin{tabular}{|c|c|c|}
\hline Variable Name & Code Options & Code Descriptions \\
\hline Study Identifier & Number & This number will be provided for all studies. \\
\hline Authors & Names & All authors' last names, separated by commas \\
\hline Year & Year & Year of publication \\
\hline Journal & $\begin{array}{l}\text { Journal name, } \\
\text { Dissertation, or Other }\end{array}$ & $\begin{array}{l}\text { Record the journal name. } \\
\text { - If the item is a dissertation, record "Dissertation." } \\
\text { - If the item is not a journal article or dissertation, record "Other." }\end{array}$ \\
\hline Publication Type & $\begin{array}{l}\text { Select one: } \\
0=\text { unknown } \\
1=\text { journal article } \\
2=\text { dissertation, thesis } \\
3=\text { book chapter } \\
4=\text { conference } \\
\text { presentation } \\
5=\text { pre-print }\end{array}$ & $\begin{array}{l}\text { Codes defined as: } \\
\text { - unknown = use this code if you are unable to determine what type of } \\
\text { publication the article is } \\
\text { - peer reviewed journal = any study from a research journal; this will be the } \\
\text { majority of articles } \\
\text { - dissertation, thesis = any study that is titled dissertation or thesis; will have } \\
\text { a university noted that the student is from }\end{array}$ \\
\hline
\end{tabular}




\begin{tabular}{|c|c|c|}
\hline & $\begin{array}{l}6=\text { report } \\
7=\text { other }\end{array}$ & $\begin{array}{l}\text { - book chapter = any study that is one part of a larger book of studies; there } \\
\text { will be no issue number } \\
\text { conference presentation = poster presentations or summaries of } \\
\text { conference presentations or proceedings; a date and location will likely be } \\
\text { included } \\
\text { - pre-print = we obtained a word document from an author of an article that } \\
\text { has not yet been published; note: the list of study identifiers will alert you } \\
\text { to a pre-print } \\
\text { - report = technical reports, reports from state departments or the U.S. } \\
\text { Department of Education, research briefs, executive summaries } \\
\text { other = use this for any other publication type that surfaces }\end{array}$ \\
\hline Location Code & $\begin{array}{l}\text { Select one: } \\
0=\text { not reported } \\
1=\text { US } \\
2=\text { non-US }\end{array}$ & $\begin{array}{l}\text { - Not reported = the authors did not report where the study took place } \\
\text { If no location is provided, refer to the location of publication (such } \\
\text { as the institution affiliation of the authors). } \\
\text { - If it's US, note this in the anecdotal code, and continue to } \\
\text { use US demographics. } \\
\text { - If it's foreign, note this in the anecdotal code, and we use } \\
\text { non-US. } \\
\text { If multiple locations are represented and nothing is reported, refer } \\
\text { to the location from which the IRB was granted. } \\
\text { U.S. = The data for the study were collected in the U.S., including } \\
\text { territories. } \quad \text { NOTE: If no explicit location (e.g., Boise, ID) is reported, but the } \\
\text { following are mentioned, use "US" for this code and explain in the } \\
\text { anecdotal code below. } \\
\text { - Head Start } \\
\text { - Southwest (or anything similar such as "midsize town in the } \\
\text { northeast") } \\
\text { U.S. }\end{array}$ \\
\hline
\end{tabular}




\begin{tabular}{|l|l|l|}
\hline Location & Name or NR & $\begin{array}{l}\text { - } \\
\text { you reported = If the authors did report where the study took place (i.e., } \\
\text { you for the previous code), put NR here as well. }\end{array}$ \\
$\begin{array}{l}\text { - Anecdotally report the location of the study with the most description you } \\
\text { can find (e.g., U.S., Midwest section of the U.S., a southern state in the } \\
\text { U.S., France, Europe, Chile, etc.) } \\
\text { If the study reports, "Boise, ID" as the location, include "Boise, ID" } \\
\text { (not just Idaho). }\end{array}$ \\
\end{tabular}

Participant Sample Size and Demographics: Basic Information Provided at the Study Level

\begin{tabular}{|l|l|l|}
\hline Variable Name & Code Options & Code Descriptions \\
\hline $\begin{array}{l}\text { Child Attrition } \\
\text { Reported }\end{array}$ & $\begin{array}{l}\text { Select one: } \\
0=\text { no } \\
1=\text { yes }\end{array}$ & $\begin{array}{r}\text { No = attrition (loss of participants from pretest to posttest or over } \\
\text { the course of the duration of the study) information was not } \\
\text { reported } \\
\text { Yes = attrition (loss of participants) was reported either as a } \\
\text { percentage (e.g., "attrition from pre to posttest was 15\%") or as } \\
\text { raw data (e.g., at pretest there were 100 participants and at } \\
\text { posttest there were 89 participants") }\end{array}$ \\
\hline Total Child Attrition & Anecdotal or NR & $\begin{array}{r}\text { Note. This refers only to loss of participants, or participants who dropped } \\
\text { out of the study. This does not refer to participants with "missing data." }\end{array}$ \\
& $\begin{array}{l}\text { Include a note about the level of attrition (e.g., 15\% of the total sample } \\
\text { was missing at post-test), or NR for studies that do not report attrition or } \\
\text { do not report total attrition. In addition, knowing if attrition is unclearly } \\
\text { presented in the method or results will be helpful. } \\
\text { Use this column if attrition is reported for a study in which there is } \\
\text { only a treatment group. }\end{array}$ \\
\hline
\end{tabular}




\begin{tabular}{|c|c|c|}
\hline $\begin{array}{l}\text { Attrition According } \\
\text { to Group }\end{array}$ & Anecdotal or NR & $\begin{array}{l}\text { Include a note about the different levels of attrition per group (e.g., } 12 \% \text { of } \\
\text { the control group and } 15 \% \text { of the treatment group). In addition, explain if } \\
\text { attrition is unclearly presented in the method or results. } \\
\text { - Use NR if no attrition is reported } \\
\text { - Use NR if there is only a treatment group (see above) }\end{array}$ \\
\hline $\begin{array}{l}\text { Child Sample Size } \\
\text { (pre-attrition) }\end{array}$ & Number or NR & $\begin{array}{l}\text { Record the total number of children who participated in the study before } \\
\text { attrition and missing data were considered (i.e., at the beginning of the } \\
\text { study, how many children were included in the analyses?) This sample size } \\
\text { includes all children in the treatment and control group(s). } \\
\text { - If no attrition is reported, use this column for the sample size. } \\
\text { - If only the post-attrition sample size is reported, use NR. } \\
\text { - If only one sample size is reported, and it is unclear if the sample } \\
\text { size reported refers to a pre- or post-attrition number, then use this } \\
\text { column to report sample size. } \\
\text { - If only one sample size is provided, but it's clearly (based on a } \\
\text { sound inference from the text) the pre-attrition sample size, use } \\
\text { this column. } \\
\text { - If multiple sample sizes are mentioned, provide the sample size that } \\
\text { was the focus on analysis. For example, if } 500 \text { children participated, } \\
\text { but the researchers chose to use on } 250 \text { for analysis, report } 250 \\
\text { (not } 500 \text { ). In this case, } 250 \text { children did not leave the study; instead, } \\
\text { the researchers just didn't focus on analyzing/reporting their data. }\end{array}$ \\
\hline $\begin{array}{l}\text { Child Sample Size } \\
\text { (post-attrition) }\end{array}$ & Number or NR & $\begin{array}{l}\text { Record the total number of children who participated in the study after } \\
\text { attrition and missing data were considered (i.e., at the end of the study, } \\
\text { how many children were included in the analyses?) This sample size } \\
\text { includes all children in the treatment and control group(s). } \\
\text { - If no attrition is reported, use the "pre-attrition" column for the } \\
\text { sample size. } \\
\text { - If only the pre-attrition sample size is reported, use NR. }\end{array}$ \\
\hline
\end{tabular}




\begin{tabular}{|c|c|c|}
\hline & & $\begin{array}{l}\text { - If only one sample size is provided, but it's clearly (based on a } \\
\text { sound inference from the text) the post-attrition sample size, use } \\
\text { this column. }\end{array}$ \\
\hline $\begin{array}{l}\text { Child Age or Grade } \\
\text { Reported }\end{array}$ & $\begin{array}{l}\text { Select one: } \\
0=\text { no } \\
1=\text { yes }\end{array}$ & $\begin{array}{l}\text { - No }=\text { no information about the age or grade of children in the study } \\
\text { was reported } \\
\text { - Yes = at least some information (mean, range, grade ranges) was } \\
\text { reported }\end{array}$ \\
\hline Child Average Age & Number in years or NR & $\begin{array}{l}\text { Report the average age as a numeral (e.g., } 4.5 \text { for } 4.5 \text { years); use NR for } \\
\text { average age Not Reported. Use two decimal places. } \\
\text { - This refers to the full sample only; if average age is reported as } \\
\text { separate values for different groups (report in next section), use } \\
\text { NR. }\end{array}$ \\
\hline $\begin{array}{l}\text { Child Age Range } \\
\text { Minimum }\end{array}$ & Number in years or NR & $\begin{array}{l}\text { If the range in child years is given in months or years (convert to years), use } \\
\text { this column to report the minimum value. }\end{array}$ \\
\hline Child Age Range & Number in years or NR & $\begin{array}{l}\text { If the range in child years is given in months or years (convert to years), use } \\
\text { this column to report the minimum value. }\end{array}$ \\
\hline $\begin{array}{l}\text { Child Grade } \\
\text { Reported }\end{array}$ & $\begin{array}{l}\text { Select one: } \\
0=\text { no } \\
1=\text { yes }\end{array}$ & $\begin{array}{l}\text { - } \mathrm{No}=\text { the grade level of child participants was not reported } \\
\text { - } \mathrm{Yes}=\text { grade of child participants was reported in some format }\end{array}$ \\
\hline Child Grade Levels & $\begin{array}{l}\text { Record all that apply: } \\
0=\text { Not applicable } \\
1=\text { First Grade } \\
2=\text { Second Grade } \\
3=\text { Third Grade } \\
4=\text { Fourth Grade and } \\
\text { Up }\end{array}$ & $\begin{array}{l}\text { Record the grade levels represented by child participants in this study; use } \\
\text { numerical order: } \\
\text { - Not applicable = Grade level was not reported; If some participants } \\
\text { are not enrolled in school (i.e., a grade level isn't reported because } \\
\text { they aren't in school), use " } 0 \text { " for not applicable. } \\
\text { - First Grade = This applies to any child listed as being in first grade }\end{array}$ \\
\hline
\end{tabular}




\begin{tabular}{|c|c|c|}
\hline & $\begin{array}{l}5=\text { PreK } / \text { Preschool } \\
6=\text { Kindergarten }\end{array}$ & $\begin{array}{l}\text { - Second Grade = This applies to any child listed as being in second } \\
\text { grade } \\
\text { - Third Grade = This applies to any child listed as being in third grade } \\
\text { - Fourth Grade and Up = This applies to any child in the study that } \\
\text { was in fourth grade or any grade above fourth grade } \\
\text { - Preschool, PreK = this applies to Head Start, preschools, } \\
\text { prekindergarten, and other preschool options reported as grades; } \\
\text { Preschool here doesn't imply the place, it refers to the } \\
\text { corresponding grade a child is in. } \\
\text { - Kindergarten = This applies to any child listed as being in } \\
\text { kindergarten; this applies to foreign studies that may indicate a } \\
\text { child was in their second year of preschool } \\
\text { Note: If the study is longitudinal and the same students are followed for } \\
\text { more than one grade level (e.g., } 1 \text { st to } 2 \text { nd grade) then you should } \\
\text { highlight the grade cells in blue to alert us that this is longitudinal and not } \\
\text { separate groups of students. }\end{array}$ \\
\hline $\begin{array}{l}\text { Child } \\
\text { GenderReported }\end{array}$ & $\begin{array}{l}\text { Select one: } \\
0=\text { no } \\
1=\text { yes }\end{array}$ & $\begin{array}{l}\text { - No = no information related to child gender was reported } \\
\text { - Yes = at least some information (raw data or \%) related to child } \\
\text { gender was reported, either at the study (total) or group level } \\
\text { (treatment, control) }\end{array}$ \\
\hline $\begin{array}{l}\text { Child Dual Language } \\
\text { Learner (DLL) Status } \\
\text { Reported }\end{array}$ & $\begin{array}{l}\text { Select one: } \\
0=\text { no } \\
1=\text { yes }\end{array}$ & $\begin{array}{l}\text { Note. This may be referred to as dual language learner (DLL), English } \\
\text { Learner (EL), English Language Learner (ELL), Multilingual Learner (ML), } \\
\text { English as a Second Language (ESL), non-native speaker, Limited English } \\
\text { Proficiency (LEP) or other related terms (terms may be different for non-US } \\
\text { studies). } \\
\text { - No = no information related to child DLL status was reported } \\
\text { - Yes = at least some information related to child DLL status was } \\
\text { reported, either at the study (total) or group level (treatment, }\end{array}$ \\
\hline
\end{tabular}




\begin{tabular}{|c|c|c|}
\hline & & $\begin{array}{l}\text { control); this includes qualitative or descriptive information (e.g., all } \\
\text { children were native speakers of the local dialect) } \\
\text { Note: DLL status typically refers to how another person or organization } \\
\text { (e.g., school) identifies or describes the learning needs of a child. }\end{array}$ \\
\hline $\begin{array}{l}\text { Languages Spoken in } \\
\text { the Home }\end{array}$ & $\begin{array}{l}\text { Select one: } \\
0=\text { no } \\
1=\text { yes }\end{array}$ & $\begin{array}{l}\text { Note. This is different than the code of DLL because we are interested in } \\
\text { capturing information related to the languages spoken in the child's home; } \\
\text { whereas DLL status is usually how someone outside of the home (e.g., } \\
\text { teacher, researcher) perceives the child, not how the family perceives their } \\
\text { home practices. Please also note that ASL is a language that Deaf children } \\
\text { or children with Deaf parents may use in the home. } \\
\text { - No = no information related to languages spoken in the home was } \\
\text { provided } \\
\text { - Yes = at least some information related to languages spoken in the } \\
\text { home was provided } \\
\text { Note: If the parents report language, include that here (not in DLL). }\end{array}$ \\
\hline $\begin{array}{l}\text { Child with or at-risk } \\
\text { of a Disability } \\
\text { Reported }\end{array}$ & $\begin{array}{l}\text { Select one: } \\
0=\text { not reported } \\
1=\text { no children with } \\
\text { disabilities or at-risk } \\
2=\text { yes, children with } \\
\text { disabilities are } \\
\text { included } \\
3=\text { yes, children with } \\
\text { risk for disabilities are } \\
\text { included } \\
4=\text { yes, both children } \\
\text { with and at-risk for } \\
\text { disabilities are } \\
\text { included }\end{array}$ & $\begin{array}{l}\text { Note. This includes all IDEA categories for disability - however, IDEA is US } \\
\text { legislation, and these terms may be slightly different for non-US studies } \\
\text { (so, you should consider any term that refers to disability). } \\
\text { - This code refers to with a disability (including but not limited to): } \\
\text { specific learning disability including a reading disability (dyslexia), } \\
\text { math disability (dyscalculia) or a writing disability (dysgraphia), } \\
\text { autism spectrum disorders (ASD), developmental delay, cognitive or } \\
\text { intellectual disability, speech language impairment, emotional } \\
\text { behavior disability or disorder, blindness or visual impairment, Deaf } \\
\text { or hard of hearing, Deaf-blindness, ADHD, Other health impairment } \\
\text { (OHI; may be used to refer to epilepsy, cerebral palsy), orthopedic } \\
\text { impairment, multiple disabilities, traumatic brain injury (TBI). }\end{array}$ \\
\hline
\end{tabular}




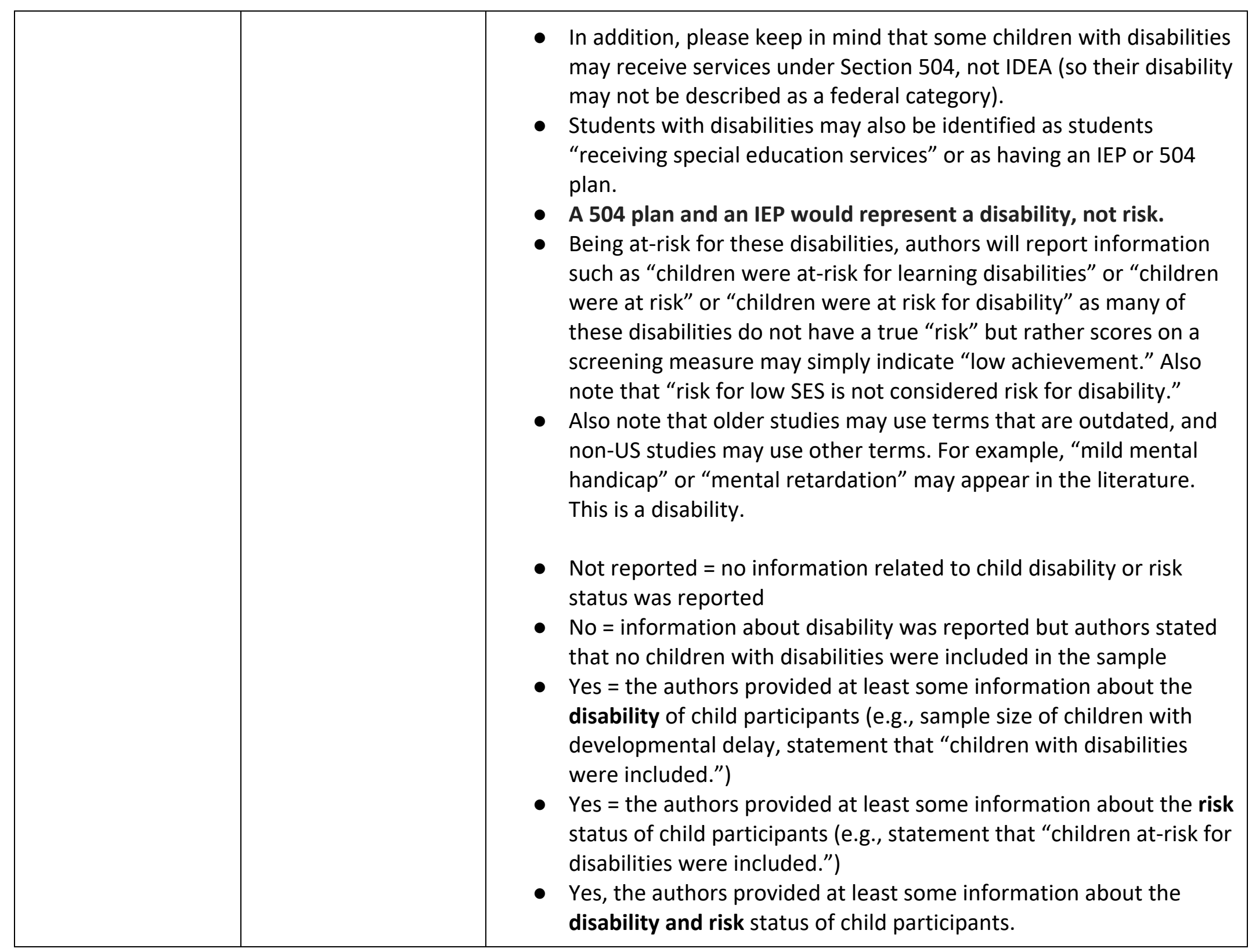

Nelson, Carter, Boedeker (2021) 


\begin{tabular}{|c|c|c|}
\hline $\begin{array}{l}\text { Child Disability or } \\
\text { Risk Information }\end{array}$ & Copy/Paste or NA & $\begin{array}{l}\text { Use NA for studies that received a code of "no, information related to child } \\
\text { disability or risk status was reported." } \\
\text { Copy and paste the specific information related to the type of disability or } \\
\text { risk children in the study had as well as sample sizes; and copy and paste } \\
\text { information related to a study reporting that children with disabilities were } \\
\text { excluded from the study. }\end{array}$ \\
\hline Child Race Reported & $\begin{array}{l}\text { Select one: } \\
0=\text { no } \\
1=\text { yes }\end{array}$ & $\begin{array}{l}\text { - No = no information related to child race/ethnicity was reported } \\
\text { - Yes = at least some information (raw data or \%) related to child } \\
\text { race/ethnicity was reported, either at the study (total) or group } \\
\text { level (treatment, control) } \\
\text { This specifically refers to if any information related to the child's } \\
\text { race/ethnicity is reported. }\end{array}$ \\
\hline Family SES Reported & $\begin{array}{l}\text { Select one: } \\
0=\text { no } \\
1=\text { yes }\end{array}$ & $\begin{array}{l}\text { Note. This may be referred to as poverty levels, socioeconomic (SES) } \\
\text { information, free/reduced price lunch, etc. Non-US studies may also use a } \\
\text { composite to calculate SES such as income and mother's level of education, } \\
\text { etc. In the Excel file, the column is named "Child SES" which we will leave } \\
\text { and just know we are referring to "Family SES" instead. } \\
\text { - No = no information related to family SES was reported } \\
\text { - Yes = at least some information related to family SES was reported, } \\
\text { either at the study (total) or group level (treatment, control); this } \\
\text { includes qualitative or descriptive information. }\end{array}$ \\
\hline $\begin{array}{l}\text { Caregiver Sample } \\
\text { Size }\end{array}$ & Number or NR & $\begin{array}{l}\text { Record the total number of caregivers/parents (primary caregivers; in } \\
\text { some cultures, this may be the mother, father, aunt/uncle, or grandparent) } \\
\text { who participated in the study after attrition and missing data were taken } \\
\text { into account (i.e., at the end of the study, how many parents were included } \\
\text { in the analyses?) } \\
\text { - If the total sample size for caregivers is not provided, use NR. }\end{array}$ \\
\hline
\end{tabular}




\begin{tabular}{|c|c|c|}
\hline $\begin{array}{l}\text { Parent/Primary } \\
\text { Caregiver Age }\end{array}$ & Anecdotal or NR & $\begin{array}{l}\text { Provide any information the study reports related to the age of the primary } \\
\text { caregiver. This might be an average age or a range. It might be presented } \\
\text { for the entire sample or different groups. Provide all information given } \\
\text { (e.g., you might provide total sample and group sample information, or just } \\
\text { total sample, depending on how authors report information). } \\
\text { - If information about the age for caregivers is not provided, use NR. }\end{array}$ \\
\hline $\begin{array}{l}\text { Information about } \\
\text { the Highest Level of } \\
\text { Education }\end{array}$ & Anecdotal or NR & $\begin{array}{l}\text { Provide all relevant information the study reports related to the highest } \\
\text { level of education for the primary caregiver(s). Oftentimes, this is } \\
\text { presented for mothers only. It might be presented for the entire sample or } \\
\text { different groups. This does not only include the highest level for the full } \\
\text { sample, but the breakdown of education attained for the full sample (e.g., } \\
50 \% \text { had a bachelor's degree; } 20 \text { percent have high school). } \\
\text { - In the Excel file, the column is named "Highest Level of Education" } \\
\text { which we will leave and just know we are referring to all relevant } \\
\text { information. } \\
\text { - If information about the highest level of education for caregivers is } \\
\text { not provided, use NR. }\end{array}$ \\
\hline
\end{tabular}

\section{Child Demographics: Group Level}

\begin{tabular}{|l|l|l|}
\hline Variable Name & Code Options & Code Descriptions \\
\hline Authors & Names & All authors' last names, separated by commas \\
\hline Year & Year & Year of publication \\
\hline Group & Name & $\begin{array}{l}\text { Include the name of the group using the following format (each group gets } \\
\text { its own row in Excel): }\end{array}$ \\
\hline
\end{tabular}




\begin{tabular}{|c|c|c|}
\hline & & $\begin{array}{l}\text { - If there is (a) one treatment group only or (b) one treatment group } \\
\text { and one control group, only use TRT and CTRL } \\
\text { - If there is more than one treatment group or control group, use a } \\
\text { descriptive naming convention such as: } \\
\text { O TRT Board Games; TRT Letter Game } \\
\text { O CTRL BAU; CTRL Active Reading Group } \\
\text { - If a study only provides information for the full sample, use FULL } \\
\text { SAMPLE } \\
\text { - If the study has only a TRT group, use “TRT, FULL SAMPLE" } \\
\text { - If a study provides information at the group level (treatment, } \\
\text { control) and at the full sample level, include only the group level } \\
\text { numbers (do not include FULL SAMPLE) unless there is a data point } \\
\text { provided for FULL SAMPLE that was not already provided in } \\
\text { TRT/CTRL. In other words, don't provide duplicate information. } \\
\text { O If you have a FULL SAMPLE row for unique data (not } \\
\text { provided in TRT/CTRL), avoid duplicating info provided by } \\
\text { the author by coding NC for not coded. This will avoid } \\
\text { duplicating info but will also let us know the info was } \\
\text { provided by authors, which is why we don't want to code } \\
\text { NR. }\end{array}$ \\
\hline Child Average Age & Number in years or NR & $\begin{array}{l}\text { Report the average age as a numeral (e.g., } 4.5 \text { for } 4.5 \text { years); use NR for } \\
\text { average age Not Reported. Use two decimal places. } \\
\text { - If average age is reported as separate values for different groups } \\
\text { use NR. }\end{array}$ \\
\hline $\begin{array}{l}\text { Child Age Range } \\
\text { Minimum }\end{array}$ & Number in years or NR & $\begin{array}{l}\text { If the range in child years is given in months or years (convert to years), use } \\
\text { this column to report the minimum value. }\end{array}$ \\
\hline
\end{tabular}




\begin{tabular}{|c|c|c|}
\hline & & $\begin{array}{l}\text { - If average age is reported as separate values for different groups } \\
\text { use NR. }\end{array}$ \\
\hline Child Age Range & Number in years or NR & $\begin{array}{l}\text { If the range in child years is given in months or years (convert to years), use } \\
\text { this column to report the minimum value. Report the range of ages } \\
\text { included ( } 4.0-6.5) \text {; use NR for average age Not Reported. } \\
\text { If average age is reported as separate values for different groups } \\
\text { use NR. }\end{array}$ \\
\hline$N$ of Females & Number or NR & $\begin{array}{l}\text { - Provide the raw number of child female participants (use numerals) } \\
\text { - Use NR when this information is not reported; including if only the } \\
\text { number of males is provided. }\end{array}$ \\
\hline$N$ of Males & Number or NR & $\begin{array}{l}\text { - Provide the raw number of child male participants (use numerals) } \\
\text { - Use or NR when this information is not reported; including if only } \\
\text { the number of females is provided. use numerals. }\end{array}$ \\
\hline Female \% & Percent or NR & $\begin{array}{l}\text { Provide the percent of child female participants; use decimals but } \\
\text { do not use a } \% \text { sign (e.g., } 89 \%=0.89 ; 42.3 \%=0.423 \text { ). Convert } \\
\text { whole numbers to full decimals. } \\
\text { - Use NR when this information is not reported; including when only } \\
\text { the percent of males is given. }\end{array}$ \\
\hline Male \% & Percent or NR & $\begin{array}{l}\text { Provide the percent of child male participants; use decimals but do } \\
\text { not use a \% sign (e.g., } 89 \%=0.89 ; 42.3 \%=0.423) \text {. Convert whole } \\
\text { numbers to full decimals. } \\
\text { Use NR when this information is not reported; including when only } \\
\text { the percent of females is given. }\end{array}$ \\
\hline $\begin{array}{l}\text { Languages Spoken in } \\
\text { the Home }\end{array}$ & Anecdotal or NR & $\begin{array}{l}\text { Provide any information for the total child sample regarding languages } \\
\text { spoken in the home. This information should be copy/paste from the } \\
\text { article, coders adding any detail where necessary. Examples include: }\end{array}$ \\
\hline
\end{tabular}




\begin{tabular}{|c|c|c|}
\hline & & $\begin{array}{l}\text { - } 100 \% \text { of children were English speakers but } 20 \% \text { of children also } \\
\text { spoke Spanish in the home. } \\
\text { - Languages spoken in the home included: English, Spanish, } \\
\text { Mandarin, and Arabic. } \\
\text { - Languages spoken in the home included: English (60\%), Spanish } \\
\text { ( } 20 \%), \text { Mandarin ( } 13 \%) \text {, and Arabic ( } 7 \%) \text {. } \\
\text { - Use NR if this information is not reported. }\end{array}$ \\
\hline $\begin{array}{l}\text { Child } N \text { with or at- } \\
\text { risk for Disability }\end{array}$ & Number or NR & $\begin{array}{l}\text { - Provide the raw number of child participants who were identified } \\
\text { as having or being at risk for a disability. } \\
\text { - Note: Risk may refer to at-risk for a disability or at-risk for academic } \\
\text { failure. It may also be referred to as "low achievement" "struggling } \\
\text { learner" or "learning difficulty." } \\
\text { - Use NR if this information is not reported. }\end{array}$ \\
\hline $\begin{array}{l}\text { Child \% with or at- } \\
\text { risk for Disability }\end{array}$ & Percent or NR & $\begin{array}{l}\text { - Provide the percent of child participants who were identified as } \\
\text { having or being at risk for a disability. } \\
\text { - Note: Risk may refer to at-risk for a disability or at-risk for academic } \\
\text { failure. It may also be referred to as "low achievement" "struggling } \\
\text { learner" or "learning difficulty." }\end{array}$ \\
\hline $\begin{array}{l}\text { Disability or Risk } \\
\text { Type }\end{array}$ & Anecdotal or NR & $\begin{array}{l}\text { Provide a qualitative and quantitative summary of the disability and risk, } \\
\text { including category labels and raw samples sizes or percentages. Make a } \\
\text { note when authors do not provide sample sizes. Examples include: } \\
\text { - Of the } 100 \text { children in the study, } 10 \text { had an identified disability (no } \\
\text { information on disability type was provided). } \\
\text { - In total, } 30 \text { children had disabilities including: developmental delay } \\
\text { ( } 80 \%) \text {, autism (15\%), speech language impairment ( } 5 \% \text { ). } \\
\text { - Of the } 100 \text { children in the study, approximately } 25 \% \text { had or were at- } \\
\text { risk for disabilities including: autism, intellectual disability, visual } \\
\text { impairment, and other health impairment (sample sizes for each } \\
\text { type were not provided). }\end{array}$ \\
\hline
\end{tabular}

Nelson, Carter, Boedeker (2021) 


\begin{tabular}{|c|c|c|}
\hline & & $\begin{array}{l}\text { - Note: Risk may refer to at-risk for a disability or at-risk for academic } \\
\text { failure. It may also be referred to as "low achievement" "struggling } \\
\text { learner" or "learning difficulty." } \\
\text { - Use NR if this information is not reported. }\end{array}$ \\
\hline \multicolumn{3}{|c|}{ U.S. Studies: Race and/or Ethnicity } \\
\hline $\begin{array}{l}\text { Child } N \text { Caucasian or } \\
\text { White }\end{array}$ & Number, NR, or NUS & $\begin{array}{l}\text { - Provide the raw number of children identified as White or } \\
\text { Caucasian }\end{array}$ \\
\hline $\begin{array}{l}\text { Child N African } \\
\text { American/Black }\end{array}$ & Number, NR, or NUS & $\begin{array}{l}\text { - Provide the raw number of children identified as African American } \\
\text { or Black }\end{array}$ \\
\hline $\begin{array}{l}\text { Child } N \text { Asian } \\
\text { American, Native } \\
\text { Hawaiian or Pacific } \\
\text { Islander }\end{array}$ & Number, NR, or NUS & $\begin{array}{l}\text { - Provide the raw number of children identified as Asian American, } \\
\text { Native Hawaiian or Pacific Islander } \\
\text { - Note, if Asian American and PI, or Native Hawaiian, are provided as } \\
\text { two different percentages, then this is a case where you would } \\
\text { need to ADD those numbers to list them here. Make a note in the } \\
\text { final column for race/ethnicity if you perform this calculation. }\end{array}$ \\
\hline Child $N$ Hispanic & Number, NR, or NUS & $\begin{array}{l}\text { - Provide the raw number of children identified as Hispanic } \\
\text { - Note: It is okay if the numbers do not add up due to differences in } \\
\text { how authors may present Hispanic/Latinx information. }\end{array}$ \\
\hline $\begin{array}{l}\text { Child } N \text { Native } \\
\text { American/ American } \\
\text { Indian }\end{array}$ & Number, NR, or NUS & $\begin{array}{l}\text { - Provide the raw number of children identified as American or } \\
\text { American Indian }\end{array}$ \\
\hline $\begin{array}{l}\text { Child } N \text { Multi-racial } \\
\text { or more than two } \\
\text { races }\end{array}$ & Number, NR, or NUS & $\begin{array}{l}\text { - Provide the raw number of children identified as multi-racial or } \\
\text { more than two races }\end{array}$ \\
\hline Child $N$ Other & Number, NR, or NUS & - Provide the raw number of children identified as Other \\
\hline
\end{tabular}




\begin{tabular}{|c|c|c|}
\hline $\begin{array}{l}\text { Child N Not } \\
\text { Reported }\end{array}$ & Number, NR, or NUS & $\begin{array}{l}\text { Note. This column is specifically for race/ethnicity in which the authors } \\
\text { specify that it was Not Reported; this does not apply to information that } \\
\text { may be missing from a study (such as you can't figure out where a } \\
\text { remaining } 5 \% \text { of the sample fits in if the numbers do not add to 100\%) } \\
\text { - Provide the raw number }\end{array}$ \\
\hline $\begin{array}{l}\text { \% Caucasian or } \\
\text { White }\end{array}$ & Percent, NR, or NUS & $\begin{array}{l}\text { - Provide the percent of children identified as White or Caucasian; } \\
\text { use decimals but do not use a } \% \text { sign (e.g., } 89 \%=0.89 ; 42.3 \%= \\
\text { 0.423). Convert whole numbers to full decimals. }\end{array}$ \\
\hline $\begin{array}{l}\% \text { African } \\
\text { American/Black }\end{array}$ & Percent, NR, or NUS & $\begin{array}{l}\text { - Provide the percent of children identified as African American or } \\
\text { Black; use decimals but do not use a } \% \text { sign (e.g., } 89 \%=0.89 ; 42.3 \% \\
=0.423 \text { ). Convert whole numbers to full decimals. }\end{array}$ \\
\hline $\begin{array}{l}\text { \% Asian American, } \\
\text { Native Hawaiian or } \\
\text { Pacific Islander }\end{array}$ & Percent, NR, or NUS & $\begin{array}{l}\text { Provide the percent of children identified as Asian American, Native } \\
\text { Hawaiian or Pacific Islander; use decimals but do not use a \% sign } \\
\text { (e.g., } 89 \%=0.89 ; 42.3 \%=0.423 \text { ). Convert whole numbers to full } \\
\text { decimals. } \\
\text { - Note, if Asian American and PI, or Native Hawaiian, are provided as } \\
\text { two different percentages, then this is a case where you would } \\
\text { need to ADD those numbers to list them here. Make a note in the } \\
\text { final column for race/ethnicity if you perform this calculation. }\end{array}$ \\
\hline \% Hispanic & Percent, NR, or NUS & $\begin{array}{l}\text { - Provide the percent of children identified as Hispanic; use decimals } \\
\text { but do not use a } \% \text { sign (e.g., } 89 \%=0.89 ; 42.3 \%=0.423 \text { ). Convert } \\
\text { whole numbers to full decimals. } \\
\text { - Note: It is okay if the percent does not add up due to differences in } \\
\text { how authors may present Hispanic/Latinx information. }\end{array}$ \\
\hline $\begin{array}{l}\% \text { Native American/ } \\
\text { American Indian }\end{array}$ & Percent, NR, or NUS & $\begin{array}{l}\text { Provide the percent of children identified as American or American } \\
\text { Indian; use decimals but do not use a } \% \text { sign (e.g., } 89 \%=0.89 \text {; } \\
42.3 \%=0.423 \text { ). Convert whole numbers to full decimals. }\end{array}$ \\
\hline
\end{tabular}




\begin{tabular}{|c|c|c|}
\hline $\begin{array}{l}\text { \% Multi-racial or } \\
\text { more than two races }\end{array}$ & Percent, NR, or NUS & $\begin{array}{l}\text { - Provide the percent of children identified as multi-racial or more } \\
\text { than two races; use decimals but do not use a \% sign (e.g., } 89 \%= \\
0.89) ; 42.3 \%=0.423 \text { ). Convert whole numbers to full decimals. }\end{array}$ \\
\hline$\%$ Other & Percent, NR, or NUS & $\begin{array}{l}\text { Provide the percent of children identified as Other; use decimals } \\
\text { but do not use a } \% \text { sign (e.g., } 89 \%=0.89 ; 42.3 \%=0.423) \text {. Convert } \\
\text { whole numbers to full decimals. }\end{array}$ \\
\hline$\%$ Not Reported & Percent, NR, or NUS & $\begin{array}{l}\text { Note. This column is specifically for race/ethnicity in which the authors } \\
\text { specify that it was Not Reported; this does not apply to information that } \\
\text { may be missing from a study (such as you can't figure out where a } \\
\text { remaining } 5 \% \text { of the sample fits in if the numbers do not add to } 100 \% \text { ) } \\
\text { - use decimals but do not use a } \% \text { sign (e.g., } 89 \%=0.89 ; 42.3 \%= \\
0.423 \text { ). Convert whole numbers to full decimals. }\end{array}$ \\
\hline $\begin{array}{l}\text { U.S. Studies Race } \\
\text { Notes }\end{array}$ & Anecdotal, NR, or NUS & $\begin{array}{l}\text { - Provide any information to race/ethnicity for US studies that did } \\
\text { not fit in the categories above, or any other helpful notes. } \\
\text { - If information is presented about children being immigrants, please } \\
\text { note that here, including undocumented parents or children. } \\
\text { - There is no need to put the information here if it is already } \\
\text { represented in the other columns. }\end{array}$ \\
\hline \multicolumn{3}{|c|}{ U.S. Studies: Socioeconomic Status } \\
\hline$N$ of FRL & Number, NR, or NUS & - Provide the raw number of child participants who qualified for FRL \\
\hline$N$ of CCS & Number, NR, or NUS & - Provide the raw number of child participants who qualified for CCS \\
\hline$N$ of Head Start & Number, NR, or NUS & $\begin{array}{l}\text { - Provide the raw number of child participants who qualified for or } \\
\text { participated in Head Start } \\
\text { - This refers to all students in Head Start, regardless of their poverty } \\
\text { level }\end{array}$ \\
\hline
\end{tabular}




\begin{tabular}{|c|c|c|}
\hline & & $\begin{array}{l}\text { - If the study states that "all participants" quality, provide the total } \\
\text { sample size here }\end{array}$ \\
\hline$N$ of < Poverty Line & Number, NR, or NUS & $\begin{array}{l}\text { - Provide the raw number of child participants who qualified as being } \\
\text { below the poverty line } \\
\text { - Note that Head Start does not equal below the poverty line, include } \\
\text { only information that specifies the exact number of families below } \\
\text { the poverty line }\end{array}$ \\
\hline$\%$ Of FRL & Percent, NR, or NUS & - Provide the percent of child participants who qualified for FRL \\
\hline$\%$ Of CCS & Percent, NR, or NUS & - Provide the percent of child participants who qualified for CCS \\
\hline$\%$ Of Head Start & Percent, NR, or NUS & $\begin{array}{l}\text { - Provide the percent of child participants who qualified for or } \\
\text { participated in Head Start } \\
\text { - This refers to all students in Head Start, regardless of their poverty } \\
\text { level } \\
\text { - If the study states that "all participants" quality, put a " } 1 \text { " here to } \\
\text { indicate } 100 \%\end{array}$ \\
\hline$\%$ of $<$ Poverty Line & Percent, NR, or NUS & $\begin{array}{l}\text { - Provide the percent of child participants who qualified as being } \\
\text { below the poverty line } \\
\text { - Note that Head Start does not equal below the poverty line, include } \\
\text { only information that specifies the exact number of families below } \\
\text { the poverty line }\end{array}$ \\
\hline $\begin{array}{l}\text { U.S. Studies SES } \\
\text { Other }\end{array}$ & Anecdotal or NR & $\begin{array}{l}\text { - If U.S. studies provide another format for describing the SES of } \\
\text { participants, include that information and raw data or percentages } \\
\text { here. } \\
\text { - If studies mention collecting this information or using it in an } \\
\text { analysis, but do not report specific details about SES, make a note } \\
\text { here. }\end{array}$ \\
\hline
\end{tabular}




\begin{tabular}{|c|c|c|}
\hline & & - Use NR if no other information about SES is provided. \\
\hline \multicolumn{3}{|c|}{$\begin{array}{l}\text { U.S. Studies: Dual Language Learner Status } \\
\text { - For any non-U.S. study, use the code NUS and move to the next section. }\end{array}$} \\
\hline Child N DLL & Number, NR, or NUS & $\begin{array}{l}\text { - Provide the raw number of child participants who were identified } \\
\text { as a dual-language learner (includes all types of categorizations - } \\
\text { e.g., DLL, EL, etc.) }\end{array}$ \\
\hline Child \% DLL & Percent, NR, or NUS & $\begin{array}{l}\text { - Provide the percent of child participants who were identified as a } \\
\text { dual-language learner (includes all types of categorizations) }\end{array}$ \\
\hline \multicolumn{3}{|l|}{ Non-U.S. Studies: } \\
\hline $\begin{array}{l}\text { Race/Ethnicity } \\
\text { International Studies }\end{array}$ & $\begin{array}{l}\text { Notes and sample } \\
\text { sizes, or NR, or US. }\end{array}$ & $\begin{array}{l}\text { Please use this column to make anecdotal notes about race/ethnicity if the } \\
\text { study was a non-U.S. study. Provide all details that you can synthesis from } \\
\text { text or tables. For example: } \\
\text { - "All students ( }=39 \text { ) in the study were Chinese." } \\
\text { - "Students in the study were all born in Germany." } \\
\text { - "Most of the students in the study }(95 \%) \text { were born in Canada and } \\
(5 \%) \text { were refugees from Somalia." }\end{array}$ \\
\hline $\begin{array}{l}\text { Non-U.S. Studies SES } \\
\text { Information }\end{array}$ & $\begin{array}{l}\text { Anecdotal, or NR, or } \\
\text { US. }\end{array}$ & $\begin{array}{l}\text { For the Non-U.S. studies summarize the information that authors provide } \\
\text { about SES in text or in the tables. Examples might include: } \\
\text { - "In our sample the highest prestige score in a household was on } \\
\text { average } \mathrm{M}=98.6(\mathrm{SD}=34.4) . " \\
\text { - "All of the included children were from middle to high income } \\
\text { families." }\end{array}$ \\
\hline $\begin{array}{l}\text { Non-U.S. studies } \\
\text { dual language } \\
\text { learners }\end{array}$ & $\begin{array}{l}\text { Anecdotal, or NR, or } \\
\text { US. }\end{array}$ & $\begin{array}{l}\text { For the Non-U.S. studies summarize the information that authors provide } \\
\text { about non-native speakers of the local or country official language, as it is } \\
\text { provided in text or in the tables. This may also be referred to as a } \\
\text { multilingual home in non-U.S. studies. Examples might include: }\end{array}$ \\
\hline
\end{tabular}




\begin{tabular}{|l|l|l|}
\hline & & $\begin{array}{l}\text { "In our sample, approximately } 10 \% \text { of children were non-native } \\
\text { German speakers. }\end{array}$ \\
& $\bullet \begin{array}{l}16 \text { children were non-native Chinese speakers, other languages } \\
\text { included English and French. }\end{array}$ \\
\hline
\end{tabular}


Coding Protocol: Methodological Information

\begin{tabular}{|c|c|c|}
\hline Variable Name & Code Options & Code Descriptions \\
\hline Study Identifier & Number & This number will be provided for all studies. \\
\hline Authors & Names & All authors' last names, separated by commas \\
\hline Year & Year & Year of publication \\
\hline Study Design & $\begin{array}{l}\text { Select one: } \\
0=\text { Not reported } \\
1=\text { Pre-test and post- } \\
\text { test } \\
2 \text { = Pre/post-test and } \\
\text { delayed post-test } \\
3 \text { = Post-test only } \\
4 \text { = Post-test only with } \\
\text { a delayed post-test } \\
5=\text { Delayed post-test } \\
\text { only } \\
6=\text { Cross-over design } \\
7=\text { Other }\end{array}$ & $\begin{array}{l}\text { NOTE: Remember that not all studies we are coding met our inclusion } \\
\text { criteria (i.e., those studies we are coding for quality only). Thus, you may } \\
\text { have studies with no pre/post, for which you should code as "7" here. } \\
\text { Codes defined as: } \\
\text { - Not reported = The authors did not provide this information. } \\
\text { - Pre-test and post-test = Researchers gave both a pre- and post- } \\
\text { test to measure the effect of the intervention. } \\
\text { - Pre-/post-test and delayed post-test(s) = Researchers gave a pre-, } \\
\text { post-, and delayed post-test (sometimes referred to as a follow-up } \\
\text { test or maintenance test) to measure the effect of the } \\
\text { intervention. } \\
\text { - Post-test only = Researchers gave only a post-test to measure the } \\
\text { effect of the treatment. } \\
\text { - Post-test only with a delayed post-test = Researchers gave only a } \\
\text { post-test to measure the effect of the treatment, followed by a } \\
\text { delayed post-test. } \\
\text { - Delayed post-test only = Researchers only provided information } \\
\text { about a follow-up test. For example, the study may be a second } \\
\text { study from the original intervention. } \\
\text { - Cross-over = Researchers used a cross-over design; usually this } \\
\text { means there is a pre-test, followed by a mid-point assessment, }\end{array}$ \\
\hline
\end{tabular}




\begin{tabular}{|c|c|c|}
\hline & & $\begin{array}{l}\text { and then at that time, the intervention groups switch, followed by } \\
\text { a post-test. Sometimes this is referred to as T1, T2, and T3. } \\
\text { Other = Authors used another design type not listed here as an } \\
\text { option (e.g., observational studies) }\end{array}$ \\
\hline Group Types & $\begin{array}{l}\text { Select one: } \\
0=\text { Not reported } \\
1=\text { Treatment group } \\
\text { only } \\
2=1 \text { treatment group } \\
\text { and } 1 \text { control group } \\
3=2 \text { or more } \\
\text { treatment groups and } \\
1 \text { or more control } \\
\text { groups } \\
4=\text { other } \\
5=\text { unclear }\end{array}$ & $\begin{array}{l}\text { Codes defined as: } \\
\text { - Not reported = the study did not report the number of treatment } \\
\text { or control groups } \\
\text { - Treatment group only = the study included only one group, and all } \\
\text { participants in the group received the treatment/intervention } \\
\text { - } 1 \text { treatment group and } 1 \text { control group = the study included only } 1 \\
\text { group that received the treatment/intervention and only } 1 \text { group } \\
\text { that did not receive the math intervention that was the focus of } \\
\text { the study (non-intervention/control group) } \\
\text { - } 2 \text { or more treatment groups and } 1 \text { or more control groups = the } \\
\text { study included multiple treatment groups (groups who received } \\
\text { different treatments/interventions), and either one or more } \\
\text { control groups (non-intervention/control group) } \\
\text { - Other = the study included one treatment group and multiple } \\
\text { control groups or some other combination of groups } \\
\text { - Unclear = it was unclear from the description which groups were } \\
\text { intervention groups or control groups and the number of } \\
\text { associated conditions. }\end{array}$ \\
\hline $\begin{array}{l}\text { Group Types } \\
\text { Information }\end{array}$ & Anecdotal & $\begin{array}{l}\text { In this cell, copy/paste a sentence or phrase from the study that describes } \\
\text { the number and type of treatment and control groups. This information } \\
\text { may be presented most succinctly in the abstract. Be sure to check the } \\
\text { method section if needed. Include all information about the group types } \\
\text { provided by the author (i.e., even if they are school based). } \\
\text { For example: } \\
\text { - } 1 \text { treatment group about board games, } 1 \text { treatment group about } \\
\text { color games, and } 1 \text { control } \\
\text { - } 1 \text { group where all participants received the treatment }\end{array}$ \\
\hline
\end{tabular}




\begin{tabular}{|c|c|c|}
\hline & & $\begin{array}{l}\text { Note: If you chose } 4 \text { (other) or } 5 \text { (unclear) for the previous code, ensure } \\
\text { that your notes make it clear why these codes were chosen. }\end{array}$ \\
\hline $\begin{array}{l}\text { Assignment to } \\
\text { condition or group }\end{array}$ & $\begin{array}{l}\text { Select one: } \\
\text { (assignment, level): } \\
0=\text { Not reported } \\
1=\text { Not applicable, } \\
\text { treatment group only } \\
2=\text { Random } \\
3=\text { Nonrandom } \\
4=\text { Matching } \\
5=\text { Regression } \\
\text { discontinuity } \\
6=\text { Other }\end{array}$ & $\begin{array}{l}\text { Select the code that represents how groups were assigned to treatment } \\
\text { and control conditions. This should be explicitly stated by the author, not } \\
\text { implied. } \\
\text { - Not reported = The authors did not provide this information } \\
\text { - Not applicable, treatment group only = Use this code when the } \\
\text { study includes only a treatment/intervention group and no control } \\
\text { group } \\
\text { - Random: Researchers used random assignment, sometimes } \\
\text { referred to as RCT, randomized control trial. Random assignment } \\
\text { would occur before anyone receives the intervention; a procedure } \\
\text { for random assignment could be placing individuals into the } \\
\text { treatment or control group based on the result of a coin flip. } \\
\text { - Nonrandom = Researchers stated they used nonrandom } \\
\text { assignment. Nonrandom assignment can include if students, } \\
\text { parents, teachers, or administrators selected students into a } \\
\text { group. } \\
\text { Matching = Researchers used matched participants (this is not the } \\
\text { same as a parent-child dyad) } \\
\text { - Regression discontinuity = Researchers used regression } \\
\text { discontinuity; this will be specified as such } \\
\text { Other = authors used another assignment procedure not listed } \\
\text { here as an option }\end{array}$ \\
\hline $\begin{array}{l}\text { Treatment Fidelity } \\
\text { Method }\end{array}$ & $\begin{array}{l}\text { Select all that apply: } \\
0=\text { no } \\
1=\text { adherence to } \\
\text { intervention } \\
\text { procedures }\end{array}$ & $\begin{array}{l}\text { This code refers to if the intervention was monitored for implementation } \\
\text { fidelity (i.e., did the interventionist implement the intervention as } \\
\text { intended). When evaluating each study, this code looks at the method(s) } \\
\text { used to measure fidelity, not the fidelity results. Include all fidelity } \\
\text { measures, whether related to the informal math intervention or not. } \\
\text { NOTES: }\end{array}$ \\
\hline
\end{tabular}




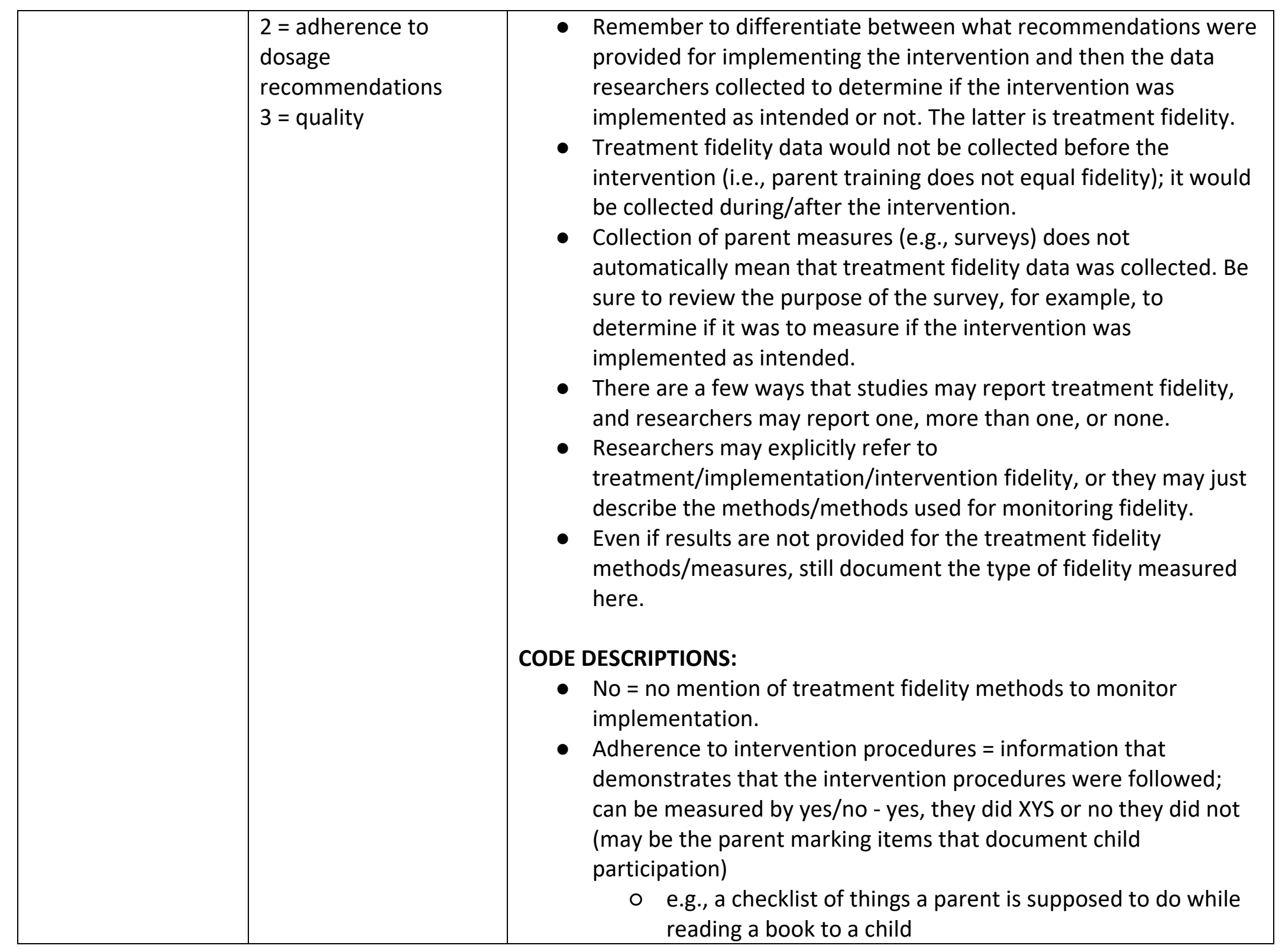




\begin{tabular}{|c|c|c|}
\hline & & $\begin{array}{l}\text { - Exposures/duration/dosage = information that demonstrates that } \\
\text { the intervention was implemented for the specific length of time } \\
\text { that was recommended } \\
\text { e.g., number of sessions, minutes per session, times per } \\
\text { day/week, etc. were documented. } \\
\text { - Quality of delivery = information that captures the quality of the } \\
\text { instruction provided by the interventionist (so this goes above and } \\
\text { beyond procedures, but instead, was information captured that } \\
\text { shows the quality of interactions between intervention agent and } \\
\text { the children during the intervention) } \\
\text { o.g., observation of a parent using high quality discussion } \\
\text { techniques/questions as they play the game with the child, } \\
\text { parent reported child engagement, or observation of } \\
\text { parent using children's response to an activity to identify } \\
\text { appropriate next steps in the activity }\end{array}$ \\
\hline $\begin{array}{l}\text { Treatment Fidelity } \\
\text { Method/Measure } \\
\text { Notes }\end{array}$ & Anecdotal or NR & $\begin{array}{l}\text { Provide a sentence or two regarding how treatment fidelity was } \\
\text { monitored/measured. Include information about who was responsible for } \\
\text { checking or reporting fidelity of implementation. Based on the type of } \\
\text { fidelity documented in the previous code, be sure to report on the } \\
\text { methods for each (if reported in the article). Also make it clear if the } \\
\text { method is for school/teacher or caregiver/informal setting (e.g., teacher } \\
\text { checklist, parent time logs, etc.) } \\
\text { Report only the method/measure here, not the results, and separate the } \\
\text { methods based on the type of fidelity (e.g., Procedures: XYZ; Dosage: XYZ; } \\
\text { Quality: XYZ). } \\
\text { Examples: } \\
\text { - Use NR when treatment fidelity information is not provided } \\
\text { - Dosage: Parents were asked to record the number of times per } \\
\text { week they played a game and to turn in the logs at the end of the } \\
\text { intervention. }\end{array}$ \\
\hline
\end{tabular}




\begin{tabular}{|c|c|c|}
\hline & & $\begin{array}{l}\text { Dosage: Children were asked to report to the researcher how } \\
\text { many times they played the game at home. } \\
\text { - Procedure: A coach from the study did a home visit and monitored } \\
\text { a play session between parents and children, checking for } \\
\text { procedural fidelity with the intervention using a checklist. }\end{array}$ \\
\hline $\begin{array}{l}\text { Treatment Fidelity } \\
\text { Results }\end{array}$ & $\begin{array}{l}\text { Select all that apply: } \\
0=\text { no } \\
1=\text { adherence to } \\
\text { intervention } \\
\text { procedures } \\
2=\text { adherence to } \\
\text { dosage } \\
\text { recommendations } \\
3=\text { quality }\end{array}$ & $\begin{array}{l}\text { For those studies that measure fidelity (as documented in the "Treatment } \\
\text { Fidelity Method" code above), this code refers to if results were provided } \\
\text { for the measures. Consider every measure listed above to determine if } \\
\text { each has reported results or not. } \\
\text { CODE DESCRIPTIONS: } \\
\text { - No = no mention of treatment fidelity results. } \\
\text { - Adherence to intervention procedures = results of the procedures } \\
\text { measures are provided. } \\
\text { o.g., data from a checklist of things a parent is supposed to } \\
\text { do while reading a book to a child } \\
\text { - Exposures/duration/dosage = results of the dosage measures are } \\
\text { provided. } \\
\text { - e.g., number of sessions, minutes per session, times per } \\
\text { day/week, etc. are described/listed/explained. } \\
\text { Quality of delivery = results of the quality measures are provided. } \\
\text { e.g., data from observations of a parent using high quality } \\
\text { discussion techniques/questions as they play the game } \\
\text { with the child is explained }\end{array}$ \\
\hline $\begin{array}{l}\text { Treatment Fidelity } \\
\text { Results Notes }\end{array}$ & Anecdotal or NR & $\begin{array}{l}\text { Provide a sentence or two regarding the level of treatment fidelity (i.e., } \\
\text { the results). Based on the method for the type of fidelity documented in } \\
\text { the previous codes, be sure to report on the results for each (if they are } \\
\text { reported in the article). Also make it clear if the results are for } \\
\text { school/teacher or caregiver/informal setting (e.g., teacher checklist, } \\
\text { parent time logs, etc.) }\end{array}$ \\
\hline
\end{tabular}




\begin{tabular}{|c|c|c|}
\hline & & $\begin{array}{l}\text { Examples: } \\
\text { - Parents reported that they implemented the intervention } 89 \% \text { of } \\
\text { the time as suggested. } \\
\text { - A coach who visited the home noted that } 75 \% \text { of the procedures } \\
\text { were implemented as prescribed. } \\
\text { - Use NR when treatment fidelity information is not provided. }\end{array}$ \\
\hline $\begin{array}{l}\text { Nature of } \\
\text { Instruction in } \\
\text { Treatment was } \\
\text { Recorded }\end{array}$ & $\begin{array}{l}\text { Select one: } \\
0=\text { no } \\
1=\text { yes, but not } \\
\text { reported in study for } \\
\text { an informal component } \\
2=\text { yes, reported in } \\
\text { study for an informal } \\
\text { component } \\
3=y e s, \text { reported in the } \\
\text { study for a formal } \\
\text { component }\end{array}$ & $\begin{array}{l}\text { This code refers to whether the researchers collected audio or visual data } \\
\text { to record the nature of instruction in the treatment/intervention group. If } \\
\text { transcripts are mentioned, that indicates audio/video was recorded. This } \\
\text { data can be collected anytime that parents provide instruction (i.e., } \\
\text { during the intervention or after the intervention if the interventionist is } \\
\text { required to provide instruction). } \\
\text { - No = the study did not report collecting any audio or visual data } \\
\text { regarding the nature of the intervention } \\
\text { - Yes, not reported = the authors collected audio and/or visual data } \\
\text { of the implementation of the intervention BUT the authors did not } \\
\text { report any excerpts from these sources in the study } \\
\text { - Yes, reported = the authors collected audio and/or visual data of } \\
\text { the implementation of the intervention AND the authors reported } \\
\text { at least one excerpt from these sources in the study } \\
\text { - Yes, reported in the study for a formal component = the authors } \\
\text { collected audio and/or visual data of the implementation of an } \\
\text { intervention, but in a formal setting (e.g., school) }\end{array}$ \\
\hline $\begin{array}{l}\text { Data Collectors and } \\
\text { Data Scorers } \\
\text { Awareness of } \\
\text { Conditions }\end{array}$ & $\begin{array}{l}\text { Select one: } \\
0=\text { not reported } \\
1=\text { blinded } \\
2=\text { unblinded }\end{array}$ & $\begin{array}{l}\text { This code refers to whether data collectors (e.g., research assistants who } \\
\text { administered the outcome measures) and/or scorers (e.g., research } \\
\text { assistants who were responsible for scoring measures) were unaware of } \\
\text { (blind to) either the purpose of the study, the group assignment of the } \\
\text { participants, or both. } \\
\text { - Not reported = The authors did not report whether data collectors } \\
\text { were unaware/blind to the study conditions }\end{array}$ \\
\hline
\end{tabular}

Nelson, Carter, Boedeker (2021) 


\begin{tabular}{|c|c|c|}
\hline & & $\begin{array}{l}\text { - Blinded = The authors reported that data collectors were } \\
\text { unaware/blind to the study conditions } \\
\text { Note: If independent coders are brought in, they are likely } \\
\text { blinded. If the coder is unaware of the hypothesis, they are } \\
\text { likely blinded. } \\
\text { - Unblinded = The authors reported that data collectors were aware } \\
\text { and not blinded to the study conditions } \\
\circ \text { Note: If a researcher is the data collector, we don't assume } \\
\text { they were unblinded if it is not stated. }\end{array}$ \\
\hline $\begin{array}{l}\text { Data Collectors/Data } \\
\text { Scorers Awareness } \\
\text { Notes }\end{array}$ & NR or Anecdotal & $\begin{array}{l}\text { Provide a sentence or two regarding any information you found about the } \\
\text { data collectors/scores' awareness of the purpose or the group assignment } \\
\text { of the participants. } \\
\text { - If your last code (awareness of conditions) was "0" (not reported), } \\
\text { your code here should be NR for not reported. } \\
\text { - If your last code was " } 1 \text { " (blinded) or " } 2 \text { " (unblinded), your code } \\
\text { here should be an anecdotal note explaining how you knew to } \\
\text { choose blinded or unblinded. }\end{array}$ \\
\hline $\begin{array}{l}\text { Interrater } \\
\text { Agreement }\end{array}$ & $\begin{array}{l}\text { Select one: } \\
0=\text { not reported } \\
1=\text { no, was reported as } \\
\text { not completed } \\
2=\text { yes, reported for at } \\
\text { least } 1 \text { child measure } \\
3=\text { yes, reported for all } \\
\text { child measures } \\
4=\text { yes, reported for at } \\
\text { least one measure (not } \\
\text { child) }\end{array}$ & $\begin{array}{l}\text { This code refers to whether authors reported double-scoring or requiring } \\
\text { that two individual data collectors scored or inputted outcome data into a } \\
\text { database to improve the reliability of the scoring or data input was } \\
\text { reliable. This refers to the scoring and data entry procedures. This refers } \\
\text { to any percentage of data that were double-scored or entered. This does } \\
\text { not refer to the individual outcome measure reliability. } \\
\text { - Not reported = the study did not mention double scoring outcome } \\
\text { data or double entering any percentage of the outcome data. } \\
\text { - No, not completed = the authors specifically state that outcome } \\
\text { data were not double-scored or entered. } \\
\text { - Yes, reported for at least } 1 \text { outcome measure but not all } \\
\text { measures = the authors reported that at least one of the outcome } \\
\text { data sources (e.g., 30\% of the math achievement data, but did not }\end{array}$ \\
\hline
\end{tabular}

Nelson, Carter, Boedeker (2021) 


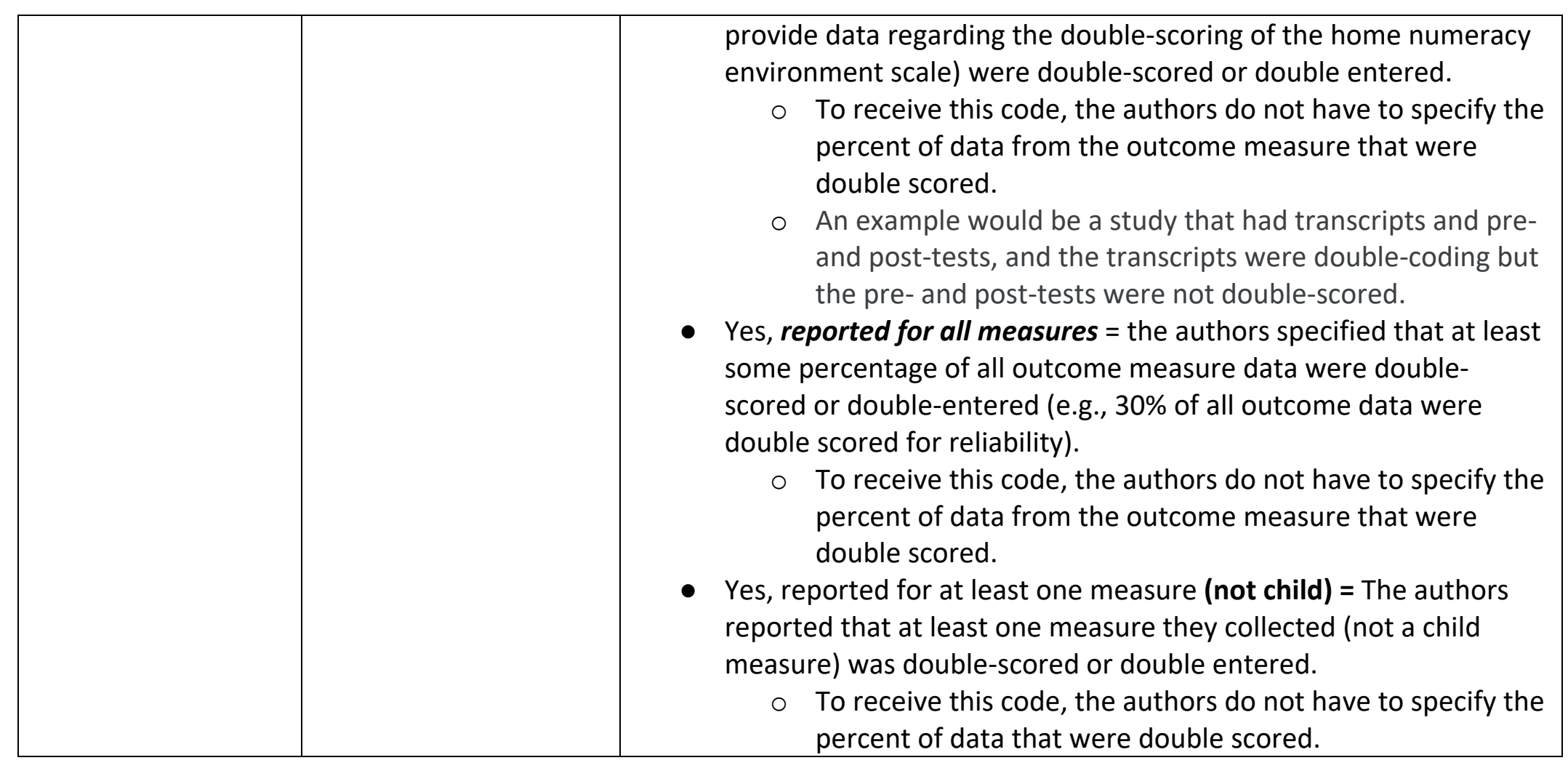


Coding Protocol: Intervention Information

\begin{tabular}{|c|c|c|}
\hline \multicolumn{3}{|c|}{ Informal Math Child Intervention } \\
\hline Variable Name & Code Options & Code Descriptions \\
\hline Study Identifier & Number & This number will be provided for all studies. \\
\hline Authors & Names & All authors' last names, separated by commas \\
\hline Year & Year & Year of publication \\
\hline $\begin{array}{l}\text { Informal Math TRT } \\
\text { Group Name }\end{array}$ & Name & $\begin{array}{l}\text { Each treatment (TRT) group receives its own line in Excel. Some codes } \\
\text { may apply broadly to all TRT groups. This information simply needs to be } \\
\text { copy/pasted to multiple lines for studies that have more than } 1 \text { treatment } \\
\text { group. However, where TRT groups often differ include math intervention } \\
\text { content, intervention activities, or dosage. This information should be } \\
\text { carefully located for each TRT group. }\end{array}$ \\
\hline $\begin{array}{l}\text { Informal Math Child } \\
\text { Intervention Agent }\end{array}$ & $\begin{array}{l}\text { Select one: } \\
0=\text { not reported } \\
1=\text { parent or another } \\
\text { adult caregiver } \\
2=\text { researcher } \\
3=\text { after school staff } \\
4=\text { library or museum } \\
\text { staff } \\
5=\text { staff at another } \\
\text { type of community } \\
\text { space } \\
6=\text { older sibling } \\
7=\text { daycare provider } \\
8=\text { mix of options } \\
9=\text { other }\end{array}$ & $\begin{array}{l}\text { The purpose of this code is to identify who provided the supplementary } \\
\text { instruction to the child participants. } \\
\text { - Note: Even if the assessment or intervention was computer } \\
\text { administered, there is still someone overseeing the child as they } \\
\text { take it; this person is considered the agent. } \\
\text { - not reported = the study did not report information about who } \\
\text { provided children with supplementary math instruction } \\
\text { - parent or other adult caregiver = the parent or other primary } \\
\text { caregiver (e.g., grandparent) provided children with } \\
\text { supplementary math instruction } \\
\text { - } \text { researcher = a researcher (including research assistants, graduate } \\
\text { students) provided children with supplementary math instruction } \\
\text { - after school staff = staff or volunteers (including older children } \\
\text { such as high school students) provided children with } \\
\text { supplementary math instruction } \\
\text { - library or museum staff provided children with supplementary } \\
\text { math instruction }\end{array}$ \\
\hline
\end{tabular}




\begin{tabular}{|c|c|c|}
\hline & & $\begin{array}{l}\text { - staff at another type of community space = staff at another type of } \\
\text { facility (e.g., outdoor play spaces, zoos, community centers, YMCA, } \\
\text { boys, and girls' clubs) provided children with supplementary math } \\
\text { instruction } \\
\text { - older sibling = older sibling of the child in the study provided } \\
\text { children with supplementary math instruction } \\
\text { - daycare = daycare provider, such as a non-relative adult who cares } \\
\text { for a child for a fee in their home provided children with } \\
\text { supplementary math instruction } \\
\text { - mix of options = more than one type of intervention agent was } \\
\text { identified who provided children with supplementary math } \\
\text { instruction } \\
\text { other = any other option regarding who provided children with } \\
\text { supplementary math instruction that is not included here as an } \\
\text { option }\end{array}$ \\
\hline $\begin{array}{l}\text { Informal Math Child } \\
\text { Intervention Agent } \\
\text { Mix or Other } \\
\text { Information }\end{array}$ & Anecdotal or NA & $\begin{array}{l}\text { If you selected the options above "mix of options" or "other" you should } \\
\text { provide a phrase that describes who the intervention agent is. }\end{array}$ \\
\hline $\begin{array}{l}\text { Informal Math Child } \\
\text { Intervention } \\
\text { Location }\end{array}$ & $\begin{array}{l}\text { Select one: } \\
0=\text { Not reported } \\
1=\text { Child's home only } \\
2=\text { After-school } \\
\text { program } \\
3=\text { Summer school } \\
\text { program } \\
4=\text { Classroom } \\
\text { intervention with an } \\
\text { at-home component } \\
5=\text { Home-based } \\
\text { daycare setting }\end{array}$ & $\begin{array}{l}\text { This code refers to ultimately where the child received the extra math } \\
\text { support or intervention because of the caregiver intervention. Remember } \\
\text { that where the outcomes/measures were collected may/may not be the } \\
\text { same places as where the intervention was conducted. } \\
\begin{array}{l}0=\text { Not reported or unclear } \\
1=\text { Child's home only: The intervention is only conducted at the } \\
\text { child's home. } \\
2=\text { After-school program: The intervention is conducted at a } \\
\text { school, but not during school hours. } \\
3=\text { Summer school program: The intervention is conducted at a } \\
\text { school, but not during the regular school year. }\end{array}\end{array}$ \\
\hline
\end{tabular}




\begin{tabular}{|c|c|c|}
\hline & $\begin{array}{l}6=\text { Museum } \\
7=\text { Library } \\
8=\text { Zoo } \\
9=\text { Community center } \\
10=\text { Other public space } \\
11=\text { Mix of one or } \\
\text { more options above }\end{array}$ & $\begin{array}{l}4=\text { Classroom intervention with an at-home component: The } \\
\text { intervention is conducted at a school, but the intervention also } \\
\text { includes some type of at-home component. } \\
5=\text { Home-based daycare setting: The intervention is conducted at } \\
\text { a daycare that is ran out of someone's home } \\
6=\text { Museum } \\
7=\text { Library } \\
8=\text { Zoo } \\
9=\text { Community center } \\
10=\text { Other public space: The intervention is conducted at some } \\
\text { public place that is not mentioned above. } \\
11=\text { Mix of one or more options above: The intervention is } \\
\text { conducted at two or more of the locations listed above. Choose } \\
\text { this option instead of selecting two from above. If this code is } \\
\text { chosen, explain in the next code. }\end{array}$ \\
\hline $\begin{array}{l}\text { Informal Math Child } \\
\text { Intervention } \\
\text { Location Mix or } \\
\text { Other Information }\end{array}$ & Anecdotal or NA & $\begin{array}{l}\text { If you selected the options above "mix of options" or "other" you should } \\
\text { provide a phrase that describes where the intervention took place. } \\
\text { - If you did not choose these two options, use "NA" here. }\end{array}$ \\
\hline \multicolumn{3}{|c|}{ Caregiver Intervention Training and Follow-Up Support } \\
\hline $\begin{array}{l}\text { Caregiver } \\
\text { Intervention Initial } \\
\text { Training }\end{array}$ & $\begin{array}{l}\text { Select one: } \\
0=\text { no or not reported. } \\
1=\text { yes }\end{array}$ & $\begin{array}{l}\text { Training refers only to the training that the caregiver receives in order to } \\
\text { provide children with the math intervention. This may be as minimal as } \\
\text { the researchers providing suggestions or as extensive as the researchers } \\
\text { leading an intensive training session. Codes defined as: } \\
\text { - No or not reported = the study did not report information about } \\
\text { the training OR specifically states that the caregiver did not receive } \\
\text { any training. } \\
\text { O Mark Not Applicable for the remaining initial training codes } \\
\text { if "no or not reported" is chosen here. }\end{array}$ \\
\hline
\end{tabular}




\begin{tabular}{|c|c|c|}
\hline & & $\begin{array}{l}\text { - Yes = the study specifically states that the caregiver received } \\
\text { training. }\end{array}$ \\
\hline $\begin{array}{l}\text { Initial Training } \\
\text { Duration/Time for } \\
\text { the Caregiver } \\
\text { Intervention }\end{array}$ & $\begin{array}{l}\text { Select one: } \\
N A=\text { not applicable } \\
0=\text { no } \\
1=\text { yes }\end{array}$ & $\begin{array}{l}\text { Is any information provided about the duration of the training? Time of } \\
\text { training can refer to training length, training intensity, or training session } \\
\text { minutes/hours. This may refer, for example, to the number of sessions a } \\
\text { parent attended about math, or the length of a training session with a } \\
\text { researcher (e.g., } 30 \text { minutes). } \\
\text { - Not applicable = The study did not include caregiver training. } \\
\text { - No = the study included information about training the caregivers, } \\
\text { but the information did not include any information about the } \\
\text { duration/time of the training. } \\
\text { - Yes = the study included information about training the caregivers, } \\
\text { and the study included specifics about the time/length/amount of } \\
\text { the training. }\end{array}$ \\
\hline $\begin{array}{l}\text { Initial Training } \\
\text { Duration/Time } \\
\text { Notes for Caregiver } \\
\text { Intervention }\end{array}$ & Anecdotal or NA & $\begin{array}{l}\text { Copy/paste a sentence or a phrase that provides all relevant detail about } \\
\text { the training duration/time for caregivers. } \\
\text { - This time refers to training but does NOT refer to follow-up } \\
\text { support. } \\
\text { O This may include the number of minutes, sessions, or hours } \\
\text { of training. } \\
\text { - Examples: } \\
\text { - Parents were trained in one 30-minute session. } \\
\text { - Parents received two } 45 \text {-minute sessions. } \\
\text { training or information related to initial training duration/time. }\end{array}$ \\
\hline $\begin{array}{l}\text { Was the caregiver } \\
\text { intervention or } \\
\text { training (initial or } \\
\text { follow up) inclusive } \\
\text { of how to facilitate } \\
\text { the activity? }\end{array}$ & $\begin{array}{l}\text { Select one: } \\
\text { NA = not applicable } \\
0=\text { no } \\
1=\text { yes }\end{array}$ & $\begin{array}{l}\text { This code refers to whether the training provided the caregiver with } \\
\text { information about the basic procedures of the intervention. In other } \\
\text { words, the parents were provided information/support on how to } \\
\text { facilitate the activity (e.g., told how the intervention should be } \\
\text { implemented, provided modeling or demonstration of the activities). For } \\
\text { this code, consider both the initial and the follow up support/training. }\end{array}$ \\
\hline
\end{tabular}




\begin{tabular}{|c|c|c|}
\hline & & $\begin{array}{l}\text { - For example, caregivers were provided with information about } \\
\text { recommended steps for implementation, or general procedures } \\
\text { for how to use or play the intervention activity. } \\
\text { O Another example - parents were allowed to practice } \\
\text { facilitating the activity with the researcher present. } \\
\text { Code descriptions: } \\
\text { - Not applicable (report NA) = The study did not have caregiver } \\
\text { initial or follow up training. } \\
\text { - No = The study had initial or follow up training, but how to } \\
\text { facilitate the activity/procedures were not included. } \\
\text { - Yes = The study had initial or follow up training that included } \\
\text { information about how to facilitate the activity/procedures. }\end{array}$ \\
\hline $\begin{array}{l}\text { Was the caregiver } \\
\text { intervention or } \\
\text { training (initial or } \\
\text { follow up) focused } \\
\text { on specific Math } \\
\text { Content related to } \\
\text { the Intervention? }\end{array}$ & $\begin{array}{l}\text { Select one: } \\
\begin{array}{l}N A=\text { not applicable } \\
0=\text { no } \\
1=\text { yes }\end{array}\end{array}$ & $\begin{array}{l}\text { This code refers to whether the training provided the caregiver with } \\
\text { specific mathematics content knowledge. Based on the math content of } \\
\text { the intervention, related content support was provided for the caregiver. } \\
\text { For this code, consider both the initial and the follow up } \\
\text { support/training. } \\
\text { - For example, were caregivers provided with information about } \\
\text { what cardinality means, or developmental information about } \\
\text { specific math skills. } \\
\text { O This does not refer to a training on a math activity or } \\
\text { strategy alone where the actual math content is not part of } \\
\text { the training. } \\
\text { Code descriptions: } \\
\text { - Not applicable (report NA) = The study did not have caregiver } \\
\text { initial or follow up training. } \\
\text { No = The study had initial or follow up training, but math content } \\
\text { was not included. } \\
\text { Yes = The study had initial or follow up training that included } \\
\text { information about math content. }\end{array}$ \\
\hline
\end{tabular}




\begin{tabular}{|c|c|c|}
\hline $\begin{array}{l}\text { Was the caregiver } \\
\text { intervention or } \\
\text { training (initial or } \\
\text { follow up) focused } \\
\text { on Basic/general } \\
\text { Information about } \\
\text { Supporting } \\
\text { Children's Math } \\
\text { Development? }\end{array}$ & $\begin{array}{l}\text { Select one: } \\
N A=\text { not applicable } \\
0=\text { no } \\
1=\text { yes }\end{array}$ & $\begin{array}{l}\text { This code refers to whether the training provided the caregiver with } \\
\text { information about best practices or strategies for supporting children's } \\
\text { mathematics development or acquisition of knowledge and skills; this } \\
\text { may also refer to development in general such as cognitive development } \\
\text { or age-appropriate activities. Aside from the intervention-specific training, } \\
\text { was more general guidance provided for supporting children's math } \\
\text { development? For this code, consider both the initial and the follow up } \\
\text { support/training. } \\
\text { - This is more about supporting development than focusing on } \\
\text { content. Oftentimes, supporting development and content go } \\
\text { together. } \\
\text { - For example, were caregivers provided with information (e.g., a } \\
\text { handout or tip sheet) about how to enhance children's } \\
\text { understanding of counting during a specific activity. How to } \\
\text { enhance understanding (mentioned here) would be different than } \\
\text { the procedures for implementing the actual intervention } \\
\text { (procedure code above). } \\
\text { Code descriptions: } \\
\text { - Not applicable (report NA) = The study did not include caregiver } \\
\text { initial or follow up training. } \\
\text { No = The study had initial or follow up training but supporting } \\
\text { math development was not included. } \\
\text { Yes = The study had initial or follow up training that included } \\
\text { supporting math development. }\end{array}$ \\
\hline $\begin{array}{l}\text { Caregiver } \\
\text { Intervention Follow- } \\
\text { Up Support }\end{array}$ & $\begin{array}{l}\text { Select one: } \\
0=\text { no or not reported } \\
1=\text { yes }\end{array}$ & $\begin{array}{l}\text { Follow-up support refers only to support after initial caregiver } \\
\text { intervention or training that a caregiver receives (e.g., a coaching session } \\
\text { with the child, home visit, additional refresher training, text message } \\
\text { reminders). Consider any training or support provided after the first/initial } \\
\text { meeting/training/support. Codes defined as: }\end{array}$ \\
\hline
\end{tabular}

Nelson, Carter, Boedeker (2021) 


\begin{tabular}{|c|c|c|}
\hline & & $\begin{array}{l}\text { - No or not reported = the study did not report information about } \\
\text { follow-up training or specifically states that the caregiver did not } \\
\text { receive any follow-up support. } \\
\text { O Mark Not Applicable for the remaining follow-up training } \\
\text { codes. } \\
\text { - Yes = the study specifically states that the caregiver received } \\
\text { follow-up support. }\end{array}$ \\
\hline $\begin{array}{l}\text { Caregiver } \\
\text { Intervention Follow- } \\
\text { Up Support Time } \\
\text { and Location Notes }\end{array}$ & Anecdotal or NA & $\begin{array}{l}\text { Include a sentence or a phrase (you can copy/paste) that provides all } \\
\text { relevant detail about the duration/frequency and location of follow-up } \\
\text { support for caregivers. This may include the number of minutes, sessions, } \\
\text { or hours of training as well as the location. For example: } \\
\text { - Parents had one home visit, lasting between } 30 \text { and } 45 \text { minutes by } \\
\text { a researcher. } \\
\text { - Parents received weekly text message reminders. } \\
\text { - Not applicable (report NA) = The study did not include caregiver } \\
\text { follow-up training. }\end{array}$ \\
\hline $\begin{array}{l}\text { Caregiver } \\
\text { Intervention Follow- } \\
\text { Up Support Nature } \\
\text { of Visit Notes }\end{array}$ & Anecdotal or NA & $\begin{array}{l}\text { Include a sentence or a phrase that provides all relevant detail about the } \\
\text { nature or purpose of the follow-up support. In other words, what was the } \\
\text { purpose or function? Was it to simply provide coaching, reminders about } \\
\text { procedures, check for fidelity of procedures, specific demonstration of a } \\
\text { skill that was requested by the parent? You can copy/paste or } \\
\text { paraphrase, but include only what the authors state, not inferences. } \\
\text { - Not applicable (report NA) = The study did not include caregiver } \\
\text { follow-up training. }\end{array}$ \\
\hline \multicolumn{3}{|c|}{ Recommended Child Intervention Duration } \\
\hline $\begin{array}{l}\text { Recommended Child } \\
\text { Intervention Length }\end{array}$ & $\begin{array}{l}\text { Anecdotal: Include } \\
\text { numeral and unit or NR }\end{array}$ & $\begin{array}{l}\text { Provide the recommended number of total days, weeks, or months of the } \\
\text { full child intervention. } \\
\text { - For example, if the study reports, "Parents were instructed to } \\
\text { implement the intervention } 3 \text { times per week over } 4 \text { weeks" you } \\
\text { would only record " } 4 \text { weeks" as that is the length of the full } \\
\text { intervention with a normal and unit. }\end{array}$ \\
\hline
\end{tabular}




\begin{tabular}{|c|c|c|}
\hline $\begin{array}{l}\text { Recommended Child } \\
\text { Intervention } \\
\text { Intensity }\end{array}$ & $\begin{array}{l}\text { Anecdotal: Include } \\
\text { numeral and unit(s) or } \\
\text { NR }\end{array}$ & $\begin{array}{l}\text { Provide the recommended number of total sessions or sessions per week, } \\
\text { month, or another unit of the child intervention. } \\
\text { - For example, if the study reports, "Parents were instructed to } \\
\text { implement the intervention } 3 \text { times per week over } 4 \text { weeks" you } \\
\text { would record " } 3 \text { times per week" as that is the total number of } \\
\text { recommended sessions in a week/month. } \\
\text { - For example, "Parents were asked to complete } 15 \text { sessions over } 2 \\
\text { weeks" you would record: "15 sessions as that is the } \\
\text { recommended number of total sessions. } \\
\text { - For example, " } 1 \text { session per } 1-2 \text { weeks" }\end{array}$ \\
\hline $\begin{array}{l}\text { Recommended Child } \\
\text { Intervention Session } \\
\text { Length }\end{array}$ & $\begin{array}{l}\text { Anecdotal: Include } \\
\text { numeral and unit or NR }\end{array}$ & $\begin{array}{l}\text { Provide the recommended length of each session of the child } \\
\text { intervention. } \\
\text { - For example, if the study reports, "Parents were asked to } \\
\text { complete } 15 \text { sessions over } 2 \text { weeks, with each session lasting } 10 \\
\text { minutes" you would only record "10 minutes" as that is the } \\
\text { recommended length of each individual session. }\end{array}$ \\
\hline \multicolumn{3}{|c|}{ Child Intervention Duration as Implemented/Reported } \\
\hline $\begin{array}{l}\text { Duration of Child } \\
\text { Intervention as } \\
\text { Implemented }\end{array}$ & $\begin{array}{l}\text { Select one: } \\
0=\text { no } \\
1=\text { yes }\end{array}$ & $\begin{array}{l}\text { Is any information provided about the duration of the implemented child } \\
\text { intervention? Time can refer to training length, training intensity, or } \\
\text { training session minutes/hours. } \\
\text { Codes defined as: } \\
\text { - No = the study did not report the actual duration that the } \\
\text { intervention was implemented (weeks, days, sessions, etc.). } \\
\text { - Yes = the study reported some information about the actual } \\
\text { frequency with which the intervention was implemented. }\end{array}$ \\
\hline $\begin{array}{l}\text { Child Intervention } \\
\text { Length as Reported }\end{array}$ & Anecdotal or NR & $\begin{array}{l}\text { Provide the number of total days, weeks, or months in total that the } \\
\text { intervention was implemented with children. Include a unit and provide } \\
\text { all information that is included. } \\
\text { - For example: Average number of weeks was } 4.2 \text { weeks. } \\
\text { - Use NR if information about length is not reported in the study. }\end{array}$ \\
\hline
\end{tabular}

Nelson, Carter, Boedeker (2021) 


\begin{tabular}{|c|c|c|}
\hline $\begin{array}{l}\text { Child Intervention } \\
\text { Intensity as } \\
\text { Reported }\end{array}$ & Anecdotal or NR & $\begin{array}{l}\text { Provide the number of total sessions or sessions per week or month that } \\
\text { the intervention was implemented with children. Include a unit and } \\
\text { provide all information that is included. } \\
\text { - For example: The average number of sessions per week was } 4.1 \\
\text { - Use NR if information about intensity is not reported in the study. }\end{array}$ \\
\hline $\begin{array}{l}\text { Child Intervention } \\
\text { Session Length as } \\
\text { Reported }\end{array}$ & Anecdotal or NR & $\begin{array}{l}\text { Provide the actual length of each session in which the intervention was } \\
\text { implemented with children. Include a unit and provide all information } \\
\text { that is included. } \\
\text { - For example: The average session length was } 20 \text { minutes and } \\
\text { ranged from } 5 \text { minutes to } 32 \text { minutes. } \\
\text { - Use NR if information about session length is not reported in the } \\
\text { study. }\end{array}$ \\
\hline \multicolumn{3}{|c|}{ Intervention Activities } \\
\hline $\begin{array}{l}\text { Quality of the } \\
\text { Description of } \\
\text { Activities }\end{array}$ & $\begin{array}{l}\text { Select one: } \\
0=\text { no } \\
1=\text { yes }\end{array}$ & $\begin{array}{l}\text { Did the study provide a description of the intervention activities in a } \\
\text { manner that allowed you to clearly understand the activities that were } \\
\text { included? In other words, did you know from reading the study (and not } \\
\text { having to make any inferences or assumptions) what activities were } \\
\text { included in the intervention? Would someone be able to easily implement } \\
\text { this intervention again based on the provided description? } \\
\text { - Note: If you choose no here, explain below and still fill out all } \\
\text { codes below with either yes or no. Even if the author doesn't } \\
\text { provide a quality description, we'll still want to know what } \\
\text { content was included. } \\
\text { - When considering quality, look to both the caregiver and the child } \\
\text { interventions. If the activity is thoroughly described in either, the } \\
\text { code should be "yes". }\end{array}$ \\
\hline $\begin{array}{l}\text { Quality of the } \\
\text { Description of } \\
\text { Activities Notes }\end{array}$ & Anecdotal or NA & $\begin{array}{l}\text { If you chose "no" above, write a brief statement explaining why. Include a } \\
\text { description of what is unclear and an example to illustrate. } \\
\text { - For example, "The counting portion of the intervention was clearly } \\
\text { explained, but the other portions were just mentioned." } \\
\text { - If you chose "yes" above, put NA. }\end{array}$ \\
\hline
\end{tabular}




\begin{tabular}{|c|c|c|}
\hline Children's Books & $\begin{array}{l}\text { Select one: } \\
0=\text { no } \\
1=\text { yes }\end{array}$ & $\begin{array}{l}\text { This refers to any intervention that recommends children's books or } \\
\text { children's literature as part of the intervention. The books can either be } \\
\text { published or researcher created. This does NOT include stories that are } \\
\text { presented as e-books or on iPad devices. }\end{array}$ \\
\hline Children's e-Books & $\begin{array}{l}\text { Select one: } \\
0=\text { no } \\
1=\text { yes }\end{array}$ & $\begin{array}{l}\text { This refers to any intervention that recommends children's e-books as } \\
\text { part of the intervention. }\end{array}$ \\
\hline $\begin{array}{l}\text { Number Board } \\
\text { Games }\end{array}$ & $\begin{array}{l}\text { Select one: } \\
0=\text { no } \\
1=\text { yes }\end{array}$ & $\begin{array}{l}\text { This refers to any intervention that recommends number board games } \\
\text { (where counting is required to move along the board) as part of the } \\
\text { intervention. For example, Chutes and Ladders, Candyland, The Number } \\
\text { Race. These board games can also be researcher created. }\end{array}$ \\
\hline $\begin{array}{l}\text { Commercially } \\
\text { Available Playing } \\
\text { Cards }\end{array}$ & $\begin{array}{l}\text { Select one: } \\
0=\text { no } \\
1=\text { yes }\end{array}$ & $\begin{array}{l}\text { This refers to any intervention that recommends commercially available } \\
\text { playing cards as part of the intervention. For example, UNO, standard } \\
\text { playing cards, Go Fish, etc. }\end{array}$ \\
\hline $\begin{array}{l}\text { Research Developed } \\
\text { Cards }\end{array}$ & $\begin{array}{l}\text { Select one: } \\
0=\text { no } \\
1=\text { yes }\end{array}$ & $\begin{array}{l}\text { Intervention that recommends cards that were specifically } \\
\text { designed/developed by the research as part of the intervention. }\end{array}$ \\
\hline Flash Cards & $\begin{array}{l}\text { Select one: } \\
0=\text { no } \\
1=\text { yes }\end{array}$ & $\begin{array}{l}\text { This refers to any intervention that recommends flash cards as part of the } \\
\text { intervention. For example, flashcards for addition facts. }\end{array}$ \\
\hline Other Games & $\begin{array}{l}\text { Select one: } \\
0=\text { no } \\
1=\text { yes }\end{array}$ & $\begin{array}{l}\text { This refers to any intervention that recommends other games as part of } \\
\text { the intervention. For example, Connect Four, checkers, or dice games. }\end{array}$ \\
\hline $\begin{array}{l}\text { Other Games } \\
\text { Information }\end{array}$ & Anecdotal or NA & $\begin{array}{l}\text { If you selected "yes" for other games, you need to describe it here. } \\
\text { If you selected "no" for other games, use NA. }\end{array}$ \\
\hline Digital Technology & $\begin{array}{l}\text { Select one: } \\
0=\text { no } \\
1=\text { yes }\end{array}$ & $\begin{array}{l}\text { This refers to any intervention that recommends technology (iPads, } \\
\text { specific apps) as part of the intervention. This does not include children's } \\
\text { e-books; keep that code separate (above). }\end{array}$ \\
\hline Digital Media & $\begin{array}{l}\text { Select one: } \\
0=\text { no } \\
1=\text { yes }\end{array}$ & $\begin{array}{l}\text { This refers to any intervention that recommends digital media (TV shows, } \\
\text { movies, Podcasts, YouTube Videos) as part of the intervention. }\end{array}$ \\
\hline
\end{tabular}




\begin{tabular}{|c|c|c|}
\hline Puzzles & $\begin{array}{l}\text { Select one: } \\
0=\text { no } \\
1=\text { yes }\end{array}$ & $\begin{array}{l}\text { This refers to any intervention that recommends puzzles as part of the } \\
\text { intervention. }\end{array}$ \\
\hline Blocks & $\begin{array}{l}\text { Select one: } \\
0=\text { no } \\
1=\text { yes }\end{array}$ & $\begin{array}{l}\text { This refers to any intervention that recommends building blocks as part of } \\
\text { the intervention. }\end{array}$ \\
\hline Patterning Materials & $\begin{array}{l}\text { Select one: } \\
0=\text { no } \\
1=\text { yes }\end{array}$ & $\begin{array}{l}\text { This refers to any intervention that recommends patterning materials as } \\
\text { part of the intervention; this may include duplicating a pattern or } \\
\text { extending a pattern. For example, using colored tiles, beads and string, } \\
\text { blocks, etc. to create patterns (e.g., lining up red-blue-red-blue blocks). }\end{array}$ \\
\hline Shape Sorters & $\begin{array}{l}\text { Select one: } \\
0=\text { no } \\
1=\text { yes }\end{array}$ & $\begin{array}{l}\text { This refers to any intervention that recommends shape sorters (or other } \\
\text { shape related materials) as part of the intervention. }\end{array}$ \\
\hline Food Routines & $\begin{array}{l}\text { Select one: } \\
0=\text { no } \\
1=\text { yes }\end{array}$ & $\begin{array}{l}\text { This refers to any intervention that recommends materials to focus on } \\
\text { related to daily food routines. This may include family mealtime, setting } \\
\text { the table, cooking, grocery shopping, or other food routines. }\end{array}$ \\
\hline $\begin{array}{l}\text { Home-School } \\
\text { Communication } \\
\text { Journals }\end{array}$ & $\begin{array}{l}\text { Select one: } \\
0=\text { no } \\
1=\text { yes }\end{array}$ & $\begin{array}{l}\text { This refers to any intervention that recommends materials to increase } \\
\text { communication between the intervention agent (e.g., the home) and } \\
\text { another organization, such as the school. This does not refer to parents } \\
\text { simply tracking the intervention. }\end{array}$ \\
\hline Conversation & $\begin{array}{l}\text { Select one: } \\
0=\text { no } \\
1=\text { yes }\end{array}$ & $\begin{array}{l}\text { This refers to any intervention that recommends materials or information } \\
\text { to enhance the type of conversations they are having with children, } \\
\text { including how to ask questions, embed math language throughout } \\
\text { routines, how to increase inquiry-based discussions, etc. }\end{array}$ \\
\hline $\begin{array}{l}\text { Nature or Outdoor } \\
\text { Learning }\end{array}$ & $\begin{array}{l}\text { Select one: } \\
0=\text { no } \\
1=\text { yes }\end{array}$ & $\begin{array}{l}\text { This refers to any intervention that recommends materials or information } \\
\text { to enhance nature or outdoor learning opportunities for children, } \\
\text { including gardening, jungle gyms, parks, etc. }\end{array}$ \\
\hline $\begin{array}{l}\text { Everyday } \\
\text { Experiences }\end{array}$ & $\begin{array}{l}\text { Select one: } \\
0=\text { no } \\
1=\text { yes }\end{array}$ & $\begin{array}{l}\text { This code refers to everyday experiences that have the intention of } \\
\text { focusing on math because of the math intervention or training (not } \\
\text { including the activities implemented as part of food routines or }\end{array}$ \\
\hline
\end{tabular}




\begin{tabular}{|c|c|c|}
\hline & & $\begin{array}{l}\text { nature/outdoor learning - we are capturing those separately). This may } \\
\text { include, but is not limited to: } \\
\text { - Laundry (e.g., sorting clothes, matching) } \\
\text { - Bathroom routines (e.g., we need to wash out hands until we } \\
\text { count to } 20 \text {, brushing teeth) } \\
\text { - Exercising (e.g., counting jumping jacks, running for } 2 \text { minutes) } \\
\text { - Listening to music (if there is a focus on scales, patterns, etc.) }\end{array}$ \\
\hline $\begin{array}{l}\text { Everyday } \\
\text { Experiences } \\
\text { Anecdotal }\end{array}$ & Anecdotal or NA & $\begin{array}{l}\text { Use this column to detail information about the everyday experience that } \\
\text { had an explicit math focus. } \\
\text { Use NA if you selected "no" for Everyday Experiences above. }\end{array}$ \\
\hline Other Activities & Anecdotal or NA & $\begin{array}{l}\text { If there is another activity that was used in this intervention study that is } \\
\text { not represented in the list above, include a note in which you identify and } \\
\text { describe the activity. } \\
\text { - For example, if links are provided but the content of the links is } \\
\text { unclear, include that here because you won't know which activity } \\
\text { above the links relate to. } \\
\text { - Use NA if there were no other activities. }\end{array}$ \\
\hline
\end{tabular}

\section{Mathematics Intervention Content}

\begin{tabular}{|l|l|l|}
\hline Variable Name & Code Options & Code Descriptions \\
\hline $\begin{array}{l}\text { Quality of the } \\
\text { Content }\end{array}$ & $\begin{array}{l}\text { Select one: } \\
0=\text { no } \\
1=\text { yes }\end{array}$ & $\begin{array}{l}\text { Did the study provide a description of the intervention math content in a } \\
\text { manner that allowed you to clearly understand the content that was } \\
\text { included? In other words, you knew from reading the study (and not } \\
\text { having to make any inferences or assumptions) what content was } \\
\text { included. } \\
\text { When considering quality, look to both the caregiver and the child } \\
\text { interventions. If the content is thoroughly described in either, the } \\
\text { code should be "yes". }\end{array}$ \\
\hline
\end{tabular}




\begin{tabular}{|c|c|c|}
\hline & & $\begin{array}{l}\text { - An example of "no" would be that the study did not mention any } \\
\text { specific math content that was included; or the authors may have } \\
\text { simply stated "an at home math intervention" or a "math } \\
\text { storybook intervention." If the description of the math is so } \\
\text { general that the only terms used are "math" or "numeracy" this is } \\
\text { an example of no. } \\
\text { - If you can pull out specific content (all of those listed below) this is } \\
\text { an example of "yes." }\end{array}$ \\
\hline $\begin{array}{l}\text { Quality of } \\
\text { Description of Math } \\
\text { Content Notes }\end{array}$ & Anecdotal or NA & $\begin{array}{l}\text { If you chose "no" above, write a brief statement explaining why. Include a } \\
\text { description of what is unclear and an example to illustrate. } \\
\text { - For example, "The counting portion of the intervention was clearly } \\
\text { explained, but the other portions were just mentioned." } \\
\text { - If you chose "yes" in the above code, use "NA" here. }\end{array}$ \\
\hline \multicolumn{3}{|c|}{ Early Numeracy Skills (organized alphabetically) } \\
\hline $\begin{array}{l}\text { Benchmark or } \\
\text { Landmark Numbers }\end{array}$ & $\begin{array}{l}\text { Select one: } \\
0=\text { no } \\
1=\text { yes }\end{array}$ & $\begin{array}{l}\text { Benchmark or landmark numbers are a reference, usually multiples of } 10 \text {, } \\
\text { for a child to reference. For example, in the problem } 8+5 \text {, a child might } \\
\text { be taught to "make } 10 \text { " to solve this. } 8+2 \text { (to make } 10 \text { ) and } 3 \text { more is } 13 \text {. }\end{array}$ \\
\hline Cardinality & $\begin{array}{l}\text { Select one: } \\
0=\text { no } \\
1=\text { yes }\end{array}$ & $\begin{array}{l}\text { Students understand the principle of cardinality when they understand } \\
\text { that the last number in a count sequence represents the total quantity. } \\
\text { - For example, if students are asked to count a set of four dots, and } \\
\text { an examiner then asks, "How many dots?" Students who } \\
\text { understand cardinality will likely immediately respond, "four" } \\
\text { while students who do not understand cardinality will likely need } \\
\text { to recount the dots before responding to the examiner. } \\
\text { - This also includes instances when an adult or another child says, } \\
\text { "give me } 2 \text { apples" and the child needs to appropriately "give" the } \\
\text { quantity requested. It is sometimes referred to as "give N task." }\end{array}$ \\
\hline $\begin{array}{l}\text { Comparison: } \\
\text { Numerals }\end{array}$ & $\begin{array}{l}\text { Select one: } \\
0=\text { no } \\
1=\text { yes }\end{array}$ & $\begin{array}{l}\text { Numeral comparison refers to the ability to discern between the most (or } \\
\text { "more") and least (or "less") value of two or more numerals. }\end{array}$ \\
\hline
\end{tabular}




\begin{tabular}{|c|c|c|}
\hline & & $\begin{array}{l}\text { This skill may also be called: Numeral Comparison, Quantity } \\
\text { Discrimination or Magnitude Comparison. This is about numerals (not } \\
\text { comparing objects) }\end{array}$ \\
\hline $\begin{array}{l}\text { Comparison: Sets or } \\
\text { Objects }\end{array}$ & $\begin{array}{l}\text { Select one: } \\
0=\text { no } \\
1=\text { yes }\end{array}$ & $\begin{array}{l}\text { Set comparison (like magnitude comparison) refers to the ability to } \\
\text { discern between the most or fewest when considering two or more } \\
\text { groups of objects. } \\
\text { This skill may also be called: Quantity Discrimination, or Magnitude } \\
\text { Comparison. This is about comparing objects, not numerals. This is not } \\
\text { the same as visual numerical comparison (see Libertus study) that is } \\
\text { typically used for evaluating ANS - approximate number system. }\end{array}$ \\
\hline $\begin{array}{l}\text { Composing or } \\
\text { Decomposing }\end{array}$ & $\begin{array}{l}\text { Select one: } \\
0=\text { no } \\
1=\text { yes }\end{array}$ & $\begin{array}{l}\text { - Composition refers to the ability to put numbers together (joining) } \\
\text { to make larger numbers or combine more than one set of objects } \\
\text { to create a larger set of objects. } \\
\text { - Conversely, decomposition refers to the ability to take apart } \\
\text { numbers (separating) to make smaller numbers or take apart a set } \\
\text { of objects to create two or more smaller sets of objects. } \\
\text { - The processes of composition and decomposition happen without } \\
\text { formal operational words (i.e., plus, minus) or symbols (i.e., }+,- \text {, } \\
\text { but instead emphasize part-whole relationships. } \\
\text { - For example, students may be presented with a set of objects, and } \\
\text { after an examiner alters the set, they may ask the student, "How } \\
\text { many objects were added?" or "How many objects were taken } \\
\text { away?" }\end{array}$ \\
\hline $\begin{array}{l}\text { Counting: } \\
\text { Correspondence }\end{array}$ & $\begin{array}{l}\text { Select one: } \\
0=\text { no } \\
1=\text { yes }\end{array}$ & $\begin{array}{l}\text { Correspondence (aka one-to-one) refers to counting a set of objects and } \\
\text { simultaneously matching each object with the associated number word. } \\
\text { In other words, a child would count a set of objects without skipping } \\
\text { objects, or double counting objects, and each object receives only one } \\
\text { number-word label. This may include counting sets or groups of objects, } \\
\text { such as blocks, toys, items of food on a plate. }\end{array}$ \\
\hline
\end{tabular}




\begin{tabular}{|c|c|c|}
\hline $\begin{array}{l}\text { Counting: Error } \\
\text { Identification }\end{array}$ & $\begin{array}{l}\text { Select one: } \\
0=\text { no } \\
1=\text { yes }\end{array}$ & $\begin{array}{l}\text { This skill refers to the ability to identify errors in counting with and } \\
\text { without objects. For example, students possess this skill if they can } \\
\text { accurately identify double counting of objects or missed number words } \\
\text { when reciting the number sequence (e.g., knowing that in "one, two, four, } \\
\text { five, six" the "three" is missing). }\end{array}$ \\
\hline Counting Principles & $\begin{array}{l}\text { Select one: } \\
0=\text { no } \\
1=\text { yes }\end{array}$ & $\begin{array}{l}\text { Instead of referring to specific counting skills, studies may refer to the five } \\
\text { counting principles (Gelman \& Gallistel, 1978): one to one } \\
\text { correspondence, stable order, cardinality, order irrelevance, abstraction. } \\
\text { Only mark this option if the study refers to the "Counting Principles" } \\
\text { specifically. }\end{array}$ \\
\hline $\begin{array}{l}\text { Counting: Sequence } \\
\text { or Verbal Counting }\end{array}$ & $\begin{array}{l}\text { Select one: } \\
0=\text { no } \\
1=\text { yes }\end{array}$ & $\begin{array}{l}\text { Verbal counting (aka rote counting) refers to stating the correct sequence } \\
\text { of number words. This can be illustrated in different variations, such as } \\
\text { counting forward from "one," counting forward from a number other } \\
\text { than "one," counting backward, and counting on (e.g., there are } 2 \text { blocks } \\
\text { on the table and I add } 3 \text { more, how many are there now, " } 3,4,5 . \text {.) }\end{array}$ \\
\hline $\begin{array}{l}\text { Counting: Skip } \\
\text { Counting }\end{array}$ & $\begin{array}{l}\text { Select one: } \\
0=\text { no } \\
1=\text { yes }\end{array}$ & $\begin{array}{l}\text { This type of counting refers to counting by a number other than } 1 \mathrm{~s} \text {, for } \\
\text { example by } 2 \mathrm{~s}(2,4,6,8, \ldots) \text { or } 5 \mathrm{~s}(5,10,15, \ldots) \text {. }\end{array}$ \\
\hline Equivalence & $\begin{array}{l}\text { Select one: } \\
0=\text { no } \\
1=\text { yes }\end{array}$ & $\begin{array}{l}\text { Skills with equivalence refer to creating an equivalent set (from a numeral } \\
\text { or set of objects) and breaking apart an initial set of objects (e.g., } 6 \\
\text { apples) into two or more equivalent sets of objects (i.e., splitting the } 6 \\
\text { apples equally among } 2 \text { people). }\end{array}$ \\
\hline Matching Quantities & $\begin{array}{l}\text { Select one: } \\
0=\text { no } \\
1=\text { yes }\end{array}$ & $\begin{array}{l}\text { Match quantity refers to the action of matching equivalent numbers } \\
\text { represented as either a set or quantity (e.g., dots), numeral, or number } \\
\text { word. For example, a child may be shown a picture of two apples and } \\
\text { asked to select from a set of numerals which numeral matches the picture } \\
\text { (i.e., 2). }\end{array}$ \\
\hline Missing Number & $\begin{array}{l}\text { Select one: } \\
0=\text { no } \\
1=\text { yes }\end{array}$ & $\begin{array}{l}\text { This skill refers to identifying the missing number that comes before or } \\
\text { after a number, or between two numbers, when provided a segment of } \\
\text { the number line. }\end{array}$ \\
\hline
\end{tabular}




\begin{tabular}{|c|c|c|}
\hline $\begin{array}{l}\text { Number Line } \\
\text { Estimation }\end{array}$ & $\begin{array}{l}\text { Select one: } \\
0=\text { no } \\
1=\text { yes }\end{array}$ & $\begin{array}{l}\text { Number line estimation refers to estimating the placement of a number } \\
\text { along a number line when considering the provided beginning and end } \\
\text { points of the number line. }\end{array}$ \\
\hline $\begin{array}{l}\text { Number Line } \\
\text { Sequencing }\end{array}$ & $\begin{array}{l}\text { Select one: } \\
0=\text { no } \\
1=\text { yes }\end{array}$ & $\begin{array}{l}\text { Number line sequencing refers to the ability to correctly sort numbers } \\
\text { (such as numerals on cards) in a specified order. } \\
\text { - For example, a child might sort cards from least to greatest. }\end{array}$ \\
\hline $\begin{array}{l}\text { Numeral } \\
\text { Identification }\end{array}$ & $\begin{array}{l}\text { Select one: } \\
0=\text { no } \\
1=\text { yes }\end{array}$ & $\begin{array}{l}\text { Correctly matching the number word or number name with the number } \\
\text { symbol. }\end{array}$ \\
\hline Number Relations & $\begin{array}{l}\text { Select one: } \\
0=\text { no } \\
1=\text { yes }\end{array}$ & $\begin{array}{l}\text { Some studies may group several early numeracy skills and use the term } \\
\text { "number relations" or "number relationships" }\end{array}$ \\
\hline Operations & $\begin{array}{l}\text { Select one: } \\
0=\text { no } \\
1=\text { yes }\end{array}$ & $\begin{array}{l}\text { Some studies may group several early numeracy skills and use the term } \\
\text { "operations" }\end{array}$ \\
\hline Ordinal Numbers & $\begin{array}{l}\text { Select one: } \\
0=\text { no } \\
1=\text { yes }\end{array}$ & $\begin{array}{l}\text { Skill with ordinal numbers refers to the ability to state an object's relative } \\
\text { placement. } \\
\text { - For example, this skill can be used when describing a person's } \\
\text { place in line as the "first" person in line, or the "second" person in } \\
\text { line. }\end{array}$ \\
\hline Place value & $\begin{array}{l}\text { Select one: } \\
0=\text { no } \\
1=\text { yes }\end{array}$ & $\begin{array}{l}\text { All numbers in our counting system, regardless of their value, are created } \\
\text { using only } 10 \text { digits }(0,1,2,3,4,5,6,7,8,9) \text {. This system is often referred } \\
\text { to as the base-ten counting system, because it uses ten unique digits that } \\
\text { are grouped repeatedly by ten to make subsequent groups of numbers } \\
\text { (NRC, 2009). We need only ten digits to represent all numbers in a } \\
\text { counting sequence because of place value, which refers to understanding } \\
\text { that the value of an individual digit in a multi-digit number depends on its } \\
\text { position (i.e., place) within the respective number. }\end{array}$ \\
\hline $\begin{array}{l}\text { Properties of } \\
\text { Addition and/or } \\
\text { Subtraction }\end{array}$ & $\begin{array}{l}\text { Select one: } \\
0=\text { no } \\
1=\text { yes }\end{array}$ & $\begin{array}{l}\text { This refers to conceptual understanding of mathematical properties that } \\
\text { are necessary to be proficient with addition and subtraction (e.g., }\end{array}$ \\
\hline
\end{tabular}




\begin{tabular}{|c|c|c|}
\hline & & $\begin{array}{l}\text { knowing that when you add one to a set the total quantity becomes } \\
\text { greater). }\end{array}$ \\
\hline $\begin{array}{l}\text { Simple Addition } \\
\text { and/or Subtraction } \\
\text { with Objects }\end{array}$ & $\begin{array}{l}\text { Select one: } \\
0=\text { no } \\
1=\text { yes }\end{array}$ & $\begin{array}{l}\text { Basic arithmetic refers to the ability to add and subtract, typically within } \\
20 \text { (i.e., sums and differences are between } 0 \text { and } 20 \text { ). This may also } \\
\text { include number combination skills generally referred to as "plus } \\
\text { one/minus one," or "two more/two less" or "doubles." Students perform } \\
\text { these actions with the use of objects (such as blocks) to help track } \\
\text { addition and subtraction processes. }\end{array}$ \\
\hline $\begin{array}{l}\text { Simple Addition } \\
\text { and/or Subtraction } \\
\text { Without Objects } \\
\text { (aka Basic Facts) }\end{array}$ & $\begin{array}{l}\text { Select one: } \\
0=\text { no } \\
1=\text { yes }\end{array}$ & $\begin{array}{l}\text { This skill is similar to simple addition and subtraction (may be referred to } \\
\text { as basic facts or number combinations) described above, except that } \\
\text { student perform these actions without the use of objects, and instead use } \\
\text { numerals. }\end{array}$ \\
\hline Subitizing & $\begin{array}{l}\text { Select one: } \\
0=\text { no } \\
1=\text { yes }\end{array}$ & $\begin{array}{l}\text { Subitizing refers to the ability to instantly recognize (i.e., subitize) } \\
\text { quantities of up to three or four (e.g., instantly recognizing that there are } \\
3 \text { drinking glasses on the table, looking at a picture and stating that there } \\
\text { are two dogs), without the use of counting (verbal and nonverbal). }\end{array}$ \\
\hline $\begin{array}{l}\text { Visual Numerical } \\
\text { Discrimination (ANS) }\end{array}$ & $\begin{array}{l}\text { Select one: } \\
0=\text { no } \\
1=\text { yes }\end{array}$ & $\begin{array}{l}\text { This refers to instant visual numerical comparison or discrimination. } \\
\text { Students are asked to visually discrimination very quickly the difference } \\
\text { between two pictures. This will always be a computer-based skill. Most } \\
\text { studies that use this will refer to it being a test of the approximate } \\
\text { number system (ANS). } \\
\text { This is different than Comparison: Sets of Objects because it's an instant } \\
\text { process and is more of a combination of comparison and subitizing but } \\
\text { should only be coded as Visual Numerical Discrimination. }\end{array}$ \\
\hline Writing Numerals & $\begin{array}{l}\text { Select one: } \\
0=\text { no } \\
1=\text { yes }\end{array}$ & $\begin{array}{l}\text { Writing numerals refers to a child practicing writing number of symbols. } \\
\text { This may be in relation to other skills, such as writing the numeral that } \\
\text { matches a set of objects (then also select "matching quantities" if this is } \\
\text { the case). }\end{array}$ \\
\hline
\end{tabular}

Nelson, Carter, Boedeker (2021) 


\begin{tabular}{|c|c|c|}
\hline Computation & $\begin{array}{l}\text { Select one: } \\
0=\text { no } \\
1=\text { yes }\end{array}$ & $\begin{array}{l}\text { This goes beyond basic facts in that students must use an algorithm to } \\
\text { solve more complex computation that requires an understanding of place } \\
\text { value. }\end{array}$ \\
\hline $\begin{array}{l}\text { Multiplication and } \\
\text { or/Division: Basic } \\
\text { Facts }\end{array}$ & $\begin{array}{l}\text { Select one: } \\
0=\text { no } \\
1=\text { yes }\end{array}$ & $\begin{array}{l}\text { Applying skills of multiplication and division with numerals. Multiplication } \\
\text { (whole number facts up to } 100 \text { and division facts within } 100 \text { with whole } \\
\text { numbers). Basic multiplication and division refer to facts that are rote } \\
\text { memorization. }\end{array}$ \\
\hline $\begin{array}{l}\text { Multiplication } \\
\text { and/or Division: } \\
\text { Principles of } \\
\text { Understanding }\end{array}$ & $\begin{array}{l}\text { Select one: } \\
0=\text { no } \\
1=\text { yes }\end{array}$ & $\begin{array}{l}\text { Understanding that multiplication refers to repeated addition or "groups } \\
\text { of" and division refers to "equal groups or sets." This does not actually } \\
\text { refer to performing multiplication or division, but it refers to } \\
\text { demonstrating the understanding of "groups" such as with pictures, } \\
\text { discussion multiplication as repeated addition, and discussion division as } \\
\text { creating equal groups. }\end{array}$ \\
\hline $\begin{array}{l}\text { Principles of } \\
\text { Fractions }\end{array}$ & $\begin{array}{l}\text { Select one: } \\
0=\text { no } \\
1=\text { yes }\end{array}$ & $\begin{array}{l}\text { Students understand that a fraction is used to represent a part of a whole. } \\
\text { This may be with a number line, diagram, area model, or set model. } \\
\text { Students may identify fractions, match fraction representations, compare } \\
\text { fractions, or find equivalent fractions. }\end{array}$ \\
\hline $\begin{array}{l}\text { Word Problem } \\
\text { Solving }\end{array}$ & $\begin{array}{l}\text { Select one: } \\
0=\text { no } \\
1=\text { yes }\end{array}$ & $\begin{array}{l}\text { This refers to real world problems where children need to apply their } \\
\text { understanding of numbers or operations. This may also be referred to as } \\
\text { story problems. }\end{array}$ \\
\hline \multicolumn{3}{|c|}{ Measurement \& Geometry (organized alphabetically) } \\
\hline $\begin{array}{l}\text { Identifying and } \\
\text { Using Measurable } \\
\text { Attributes }\end{array}$ & $\begin{array}{l}\text { Select one: } \\
0=\text { no } \\
1=\text { yes }\end{array}$ & $\begin{array}{l}\text { This skill refers to identifying objects (shapes, lines, other items) as the } \\
\text { same or different on the attributes that can be measured (e.g., length, } \\
\text { height, weight) and possibly using the attributes for comparison or to } \\
\text { order objects by an attribute (longest stick to shortest stick). }\end{array}$ \\
\hline Measuring Objects & $\begin{array}{l}\text { Select one: } \\
0=\text { no } \\
1=\text { yes }\end{array}$ & $\begin{array}{l}\text { This skill refers to using standard and nonstandard measurements for } \\
\text { measuring objects. For example, using a ruler, or a nonstandard unit of } \\
\text { measure (e.g., using the paper clips) to determine the length of a block. } \\
\text { For example, the book may be } 11 \text { inches long, or it may be } 12 \text { paper clips } \\
\text { long. This refers to all units of measure. }\end{array}$ \\
\hline
\end{tabular}

Nelson, Carter, Boedeker (2021) 


\begin{tabular}{|c|c|c|}
\hline Navigation & $\begin{array}{l}\text { Select one: } \\
0=\text { no } \\
1=\text { yes }\end{array}$ & $\begin{array}{l}\text { This skill refers to using relative position, spatial relations, and vocabulary } \\
\text { to understand, discuss, and create navigational directions. } \\
\text { - For example: Take } 10 \text { steps forward, turn left, and walk } 5 \text { more } \\
\text { steps. }\end{array}$ \\
\hline Relative Position & $\begin{array}{l}\text { Select one: } \\
0=\text { no } \\
1=\text { yes }\end{array}$ & $\begin{array}{l}\text { This skill refers to describing relative positions or objects such as "above, } \\
\text { below, next to, under." }\end{array}$ \\
\hline $\begin{array}{l}\text { Shapes: Building or } \\
\text { Composing }\end{array}$ & $\begin{array}{l}\text { Select one: } \\
0=\text { no } \\
1=\text { yes }\end{array}$ & $\begin{array}{l}\text { This skill refers to drawing shapes or forming shapes with smaller shapes } \\
\text { or filling in templates with given pieces to form a new shape. This includes } \\
\text { 2D and 3D shapes. }\end{array}$ \\
\hline $\begin{array}{l}\text { Shapes: Describing } \\
\text { Their Attributes }\end{array}$ & $\begin{array}{l}\text { Select one: } \\
0=\text { no } \\
1=\text { yes }\end{array}$ & $\begin{array}{l}\text { This skill refers to describing shapes and their attributes, such as by the } \\
\text { number of sides or relative size. This includes } 2 D \text { and 3D shapes. }\end{array}$ \\
\hline Shapes: Identifying & $\begin{array}{l}\text { Select one: } \\
0=\text { no } \\
1=\text { yes }\end{array}$ & $\begin{array}{l}\text { This skill may refer to identifying shapes by their name or being given a } \\
\text { shape name and identifying the matching shape, including finding shapes } \\
\text { in their environment. This includes 2D and 3D shapes. }\end{array}$ \\
\hline \multicolumn{3}{|c|}{ Data Analysis \& Probability (organized alphabetically) } \\
\hline Collecting Data & $\begin{array}{l}\text { Select one: } \\
0=\text { no } \\
1=\text { yes }\end{array}$ & $\begin{array}{l}\text { This skill refers to children collecting data (e.g., tallying snack choices) to } \\
\text { identify trends, totals, etc. within the data. } \\
\text { - For example, which snack has the most tallies or how many more } \\
\text { tallies do cookies have compared to apples. }\end{array}$ \\
\hline $\begin{array}{l}\text { Organizing or } \\
\text { Sorting }\end{array}$ & $\begin{array}{l}\text { Select one: } \\
0=\text { no } \\
1=\text { yes }\end{array}$ & $\begin{array}{l}\text { This skill refers to early data analysis skills of sorting objects based on } \\
\text { their attributes (e.g., number of sides, weight) or using sorting to solve } \\
\text { problems, or organizing data into categories. Use this option when the } \\
\text { skill is referred to as a data analysis or probability specific skill in the } \\
\text { intervention study. }\end{array}$ \\
\hline Representing data & $\begin{array}{l}\text { Select one: } \\
0=\text { no } \\
1=\text { yes }\end{array}$ & $\begin{array}{l}\text { This skill refers to representing data, such as by creating a chart, bar } \\
\text { graph, line plot, picture, etc. }\end{array}$ \\
\hline
\end{tabular}




\begin{tabular}{|c|c|c|}
\hline $\begin{array}{l}\text { Representing } \\
\text { Problems with } \\
\text { Equations }\end{array}$ & $\begin{array}{l}\text { Select one: } \\
0=\text { no } \\
1=\text { yes }\end{array}$ & $\begin{array}{l}\text { This skill refers to number and operations problems that children } \\
\text { represent with equations (e.g., } 5 \times 5=25 \text { ). }\end{array}$ \\
\hline $\begin{array}{l}\text { Sequencing and } \\
\text { Patterns }\end{array}$ & $\begin{array}{l}\text { Select one: } \\
0=\text { no } \\
1=\text { yes }\end{array}$ & $\begin{array}{l}\text { This skill refers to recognizing, duplicating, or extending simple patterns } \\
\text { (e.g., number patterns, color patterns, shape patterns). }\end{array}$ \\
\hline \multicolumn{3}{|c|}{ Other Mathematics Skills (organized alphabetically) } \\
\hline Logico-Mathematics & $\begin{array}{l}\text { Select one: } \\
0=\text { no } \\
1=\text { yes }\end{array}$ & $\begin{array}{l}\text { This term is typically used to describe skills like classification (classifying } \\
\text { objects by a measurable attribute), seriation (arranging objects by size), } \\
\text { and sorting (usually goes with classification). Select this option only when } \\
\text { the study specifically refers to the skills as logico-mathematics. }\end{array}$ \\
\hline Math Language & $\begin{array}{l}\text { Select one: } \\
0=\text { no } \\
1=\text { yes }\end{array}$ & $\begin{array}{l}\text { This refers to interventions that focus on teaching children about specific } \\
\text { mathematics vocabulary (discipline specific terminology). This may be in } \\
\text { written or oral form. This may be referred to as "math talk" or "number } \\
\text { talk." }\end{array}$ \\
\hline Money & $\begin{array}{l}\text { Select one: } \\
0=\text { no } \\
1=\text { yes }\end{array}$ & $\begin{array}{l}\text { This skill refers to identifying the value of coins and bills and using money } \\
\text { to solve problems. }\end{array}$ \\
\hline Problem Solving & $\begin{array}{l}\text { Select one: } \\
0=\text { no } \\
1=\text { yes }\end{array}$ & $\begin{array}{l}\text { Problem solving involves using logic or reasoning to solve a task or a set of } \\
\text { related tasks for which there is no immediately apparent solution. This is } \\
\text { not the same as word problem solving. }\end{array}$ \\
\hline $\begin{array}{l}\text { Scientific Inquiry or } \\
\text { Reasoning }\end{array}$ & $\begin{array}{l}\text { Select one: } \\
0=\text { no } \\
1=\text { yes }\end{array}$ & $\begin{array}{l}\text { Inquiry typically refers to a set of skills that are a process: children engage } \\
\text { in observing, questioning, predicting, evaluating, and concluding. }\end{array}$ \\
\hline Tell and Write Time & $\begin{array}{l}\text { Select one: } \\
0=\text { no } \\
1=\text { yes }\end{array}$ & $\begin{array}{l}\text { "Tell and write time in hours and half-hours using analog and digital } \\
\text { clocks" (CCSS). }\end{array}$ \\
\hline $\begin{array}{l}\text { Other Math } \\
\text { Intervention } \\
\text { Content }\end{array}$ & Anecdotal or NA & $\begin{array}{l}\text { - Use NA if you have nothing to report. } \\
\text { - Use this cell to report any other math skills that the author } \\
\text { described but do not fit into the above categories. } \\
\text { - Examples: Principles related to volume/capacity }\end{array}$ \\
\hline
\end{tabular}




\begin{tabular}{|l|l|l|}
\hline & - $\begin{array}{l}\text { NOTE: "Number sense" is a term that a lot of researchers use } \\
\text { differently, and most often it means a set of early numeracy skills } \\
\text { (most often a combination of subitizing, counting, comparison, } \\
\text { and number recognition). Because it's a term that is not agreed } \\
\text { upon by researchers and it refers to a set of skills, it's best if we } \\
\text { put that here. }\end{array}$ \\
\hline
\end{tabular}

The Control/Comparison Condition: Study Level Information

\begin{tabular}{|c|c|c|}
\hline Variable Name & Code Options & Code Descriptions \\
\hline Study Identifier & Number & This number will be provided for all studies. \\
\hline Authors & Names & All authors' last names, separated by commas \\
\hline Year & Year & Year of publication \\
\hline TRT Name & Name & $\begin{array}{l}\text { This is where we need to link the TRT group(s) that refer to this control } \\
\text { group. } \\
\text { - If there is more than one treatment group, list them here } \\
\text { separated by a semicolon (e.g., TRT big; TRT small) and in } \\
\text { alphabetical order. } \\
\text { - If the study has only a TRT group, you still need to put a line in the } \\
\text { CTRL tab and respond to the item below. }\end{array}$ \\
\hline Control Condition & $\begin{array}{l}\text { Select one: } \\
0=\text { no } \\
1=\text { yes }\end{array}$ & $\begin{array}{l}\text { This code refers to whether there was at least } 1 \text { control or comparison } \\
\text { condition in the study. } \\
\text { - No = there was only a treatment group(s) in the study and no } \\
\text { control. NOTE: If you select this option, use NA for all remaining } \\
\text { codes. } \\
\text { - Yes = there was a control condition. }\end{array}$ \\
\hline CTRL Name & Name or NA & $\begin{array}{l}\text { Each CTRL group receives its own line in Excel. } \\
\text { - If the study has only a TRT group, you still need to put a line in the } \\
\text { CTRL tab and respond to the item below. }\end{array}$ \\
\hline
\end{tabular}




\begin{tabular}{|c|c|c|}
\hline Control Activities & $\begin{array}{l}\text { Select one: } \\
0=\text { NA } \\
1=\text { no, BAU } \\
2=\text { no, not described } \\
3=\text { yes }\end{array}$ & $\begin{array}{l}\text { Did the study provide any information on the type of activities that were } \\
\text { included in the control condition (e.g., books, blocks, puzzles, reading } \\
\text { activities, outdoor activities)? } \\
\text { - NA = select this option if there wasn't a control condition. } \\
\text { - No, BAU and not described = the study specified that the control } \\
\text { condition was business as usual (BAU) and the study did not } \\
\text { describe the conduction any further than BAU } \\
\text { O Even if the term "BAU" is not explicitly stated, still use that } \\
\text { code if the definition above applies. } \\
\text { - No, not described = the study did not refer to the control as } \\
\text { business as usual and the control group received some sort of } \\
\text { support, but it was not described in terms of the types of activities } \\
\text { in the control condition. } \\
\text { - Yes, the study provided information on at least one type of activity } \\
\text { in the control condition. This can include control conditions called } \\
\text { BAU if the BAU activities are also described. }\end{array}$ \\
\hline $\begin{array}{l}\text { Types of Control } \\
\text { Activities }\end{array}$ & Anecdotal, NA, or NR & $\begin{array}{l}\text { Write 1-2 sentences describing the control condition activities. Use: } \\
\text { - NA when there was not a control condition } \\
\text { - NR when there was a control condition, but it is not described or } \\
\text { simply referred to as business as usual (BAU) without further } \\
\text { detail. }\end{array}$ \\
\hline Control Content & $\begin{array}{l}\text { Select one: } \\
0=\text { NA } \\
1=\text { no, BAU } \\
2=\text { no, not described } \\
3=\text { yes }\end{array}$ & $\begin{array}{l}\text { Did the study provide any information on the type of content (math, } \\
\text { reading, play) included in the control condition? } \\
\text { - NA = select this option if there wasn't a control condition. } \\
\text { - No, BAU and not described = the study specified that the control } \\
\text { condition was business as usual and the study did not describe the } \\
\text { BAU content. } \\
\text { - No, not described = the study did not describe the types of } \\
\text { content in the control condition. }\end{array}$ \\
\hline
\end{tabular}




\begin{tabular}{|c|c|c|}
\hline & & $\begin{array}{l}\text { - Yes, the study provided some information on the type of content } \\
\text { in the control condition. This can include BAU conditions in which } \\
\text { content is also described. }\end{array}$ \\
\hline $\begin{array}{l}\text { Types of Control } \\
\text { Content }\end{array}$ & Anecdotal, NA, or NR & $\begin{array}{l}\text { Write 1-2 sentences describing the control condition content. Use: } \\
\text { - NA when there was not a control condition } \\
\text { - described } \\
\text { Examples include: } \\
\text { "The control condition was an active control where parents were } \\
\text { instructed to read storybooks not pertaining to math to children. Parents } \\
\text { were provided with materials." } \\
\text { "The control condition was described as "business as usual" and did not } \\
\text { provide specific information about content or what instruction looked } \\
\text { like." }\end{array}$ \\
\hline Control Time & $\begin{array}{l}\text { Select one: } \\
0=\text { NA } \\
1=\text { no, BAU } \\
2=\text { no, not described } \\
3=\text { yes }\end{array}$ & $\begin{array}{l}\text { Did the study provide any information on the time/duration that the } \\
\text { control condition received support? } \\
\text { - NA = select this option if there wasn't a control condition. } \\
\text { - No, BAU and not described = the study specified that the control } \\
\text { condition was business as usual and did not receive any additional } \\
\text { support. } \\
\text { - No, not described = the study did not describe time/duration of } \\
\text { the additional support students received. } \\
\text { - Yes, the study provided some information on time of the control } \\
\text { condition (e.g., "same amount as intervention" or "twice a } \\
\text { week."). This may include BAU conditions in which the authors } \\
\text { also provide details related to the time. }\end{array}$ \\
\hline $\begin{array}{l}\text { Control Time } \\
\text { Described }\end{array}$ & Anecdotal, NA, or NR & $\begin{array}{l}\text { Write 1-2 sentences describing the control condition time. Use: } \\
\text { - NA when there was not a control condition } \\
\text { - NR when there was a control condition, but it was BAU or not } \\
\text { described }\end{array}$ \\
\hline
\end{tabular}




\begin{tabular}{|c|c|c|}
\hline $\begin{array}{l}\text { Nature of } \\
\text { Instruction in the } \\
\text { Control Condition } \\
\text { was Documented or } \\
\text { Reported }\end{array}$ & $\begin{array}{l}\text { Select one: } \\
0=\text { NA } \\
1=\text { no } \\
2=\text { yes }\end{array}$ & $\begin{array}{l}\text { This code refers to whether there was any documentation of the nature } \\
\text { of the instruction in the control condition (e.g., audio, or visual data } \\
\text { collection, someone entered the home and observed instruction). } \\
\text { - NA = select this option if there wasn't a control condition. } \\
\text { - No = the study did not describe efforts to document the nature of } \\
\text { the instruction in the control condition. } \\
\text { - Yes, the study provided information about how the nature of the } \\
\text { instruction in the control condition was documented. }\end{array}$ \\
\hline $\begin{array}{l}\text { Nature of Control } \\
\text { Described }\end{array}$ & Anecdotal, NA, or NR & $\begin{array}{l}\text { Write } 1-2 \text { sentences describing how the nature of the control condition } \\
\text { was documented. Use: } \\
\text { - NA when there was not a control condition } \\
\text { - NR when there was a control condition, but it was not described }\end{array}$ \\
\hline
\end{tabular}




\section{Coding Protocol: Outcome Measures}

\begin{tabular}{|c|c|c|}
\hline Variable Name & Code Options & Code Descriptions \\
\hline Study Identifier & Number & This number will be provided for all studies. \\
\hline Authors & Names & All authors' last names, separated by commas \\
\hline Year & Year & Year of publication \\
\hline Meta or Quality & $\begin{array}{l}\text { Select one: } \\
1 \text { = meta } \\
2 \text { = quality }\end{array}$ & $\begin{array}{l}\text { Use the Phase } 4 \text { tab of the included studies spreadsheet (column B) to } \\
\text { determine if the study that this measure is a part of will be included in the } \\
\text { meta-analysis or will be used for the quality paper. }\end{array}$ \\
\hline Measure Name & Anecdotal & $\begin{array}{l}\text { Report the official measure name. This may be a title of a norm- } \\
\text { referenced measure (e.g., Woodcock Johnson-III), or it may be an informal } \\
\text { name for a researcher developed measure (e.g., number skills). } \\
\text { O If the researcher uses both the whole name and an } \\
\text { abbreviation, provide the whole name with the } \\
\text { abbreviation in parentheses - e.g. Early Mathematics } \\
\text { Measures (EMM). } \\
\text { - For math achievement measures, use the preassigned naming } \\
\text { conventions for studies that are both in the meta-analysis and in } \\
\text { the quality paper. } \\
\text { - Subtest names of math achievement measures will be listed in the } \\
\text { linked document above. } \\
\text { O Check this list regularly and add to it as needed (for any } \\
\text { subtests, not just math achievement, that are not there) so } \\
\text { that each coder pair codes for (and uses the same name } \\
\text { for) each subtest. } \\
\text { Be sure to include the name of the measure itself (not the concept } \\
\text { that is being measured). } \\
\text { For example, Libertus measured the precision of children's } \\
\text { ANS for visual arrays by administering a version of } \\
\text { Panamath, a freely available non-symbolic numerical }\end{array}$ \\
\hline
\end{tabular}




\begin{tabular}{|c|c|c|}
\hline & & $\begin{array}{l}\text { comparison task. For the measure name, list "version of } \\
\text { Panamath". } \\
\text { Note also that sometimes the authors will only refer to the } \\
\text { content as the name of the measure (e.g., letter } \\
\text { identification). }\end{array}$ \\
\hline Measure Citation & Anecdotal or NR & $\begin{array}{l}\text { - Include the full APA citation of the measure, if provided. Be sure to } \\
\text { check the reference list to ensure that the citation is for a specific } \\
\text { measure and is not just citing another study that used the } \\
\text { measure. } \\
\text { O For example: } \\
\text { Ginsburg, H.P., \& Baroody, A.J. (1990). Test of Early } \\
\text { Mathematical Ability (2nd ed.). Austin, TX: Pro-Ed. } \\
\text { - If you find a measure that has a citation, tag Hannah and } \\
\text { Gena on the codebook. Give us the author/year of the } \\
\text { study so we can double check the citation and add it to our } \\
\text { list } \\
\text { - If the measure was adapted from an existing measure include } \\
\text { [adapted from: CITATION]. } \\
\text { If no citation was provided, code "NR" here. }\end{array}$ \\
\hline $\begin{array}{l}\text { Publication Type of } \\
\text { the Measure }\end{array}$ & $\begin{array}{l}\text { Select one: } \\
0=\text { unclear } \\
1=\text { norm-referenced } \\
2=\text { researcher } \\
\text { developed } \\
3=\text { other }\end{array}$ & $\begin{array}{l}\text { This code refers to the publication type of the measure. We do not } \\
\text { provide a "not reported" option, because even though some measures } \\
\text { will not be identified as "norm-referenced" they are common measures } \\
\text { (e.g., WJ-III) and are known to be norm-referenced even if authors do not } \\
\text { report it. } \\
\text { - Unclear = it is unclear from the description of the measure if the } \\
\text { measure is norm-referenced or not (e.g., this may be especially } \\
\text { true for non-U.S. studies if norm-referenced measures are not } \\
\text { those typically used in US studies). } \\
\text { o If you select this code for a measure, this will need to be } \\
\text { checked by Gena to confirm. }\end{array}$ \\
\hline
\end{tabular}




\begin{tabular}{|c|c|c|}
\hline & & $\begin{array}{l}\text { - Norm-referenced = refers to measures that are typically published } \\
\text { by companies and were developed with rigorous and standardized } \\
\text { procedures. } \\
\text { To determine if a measure is norm-referenced, first check } \\
\text { to see if the author describes it as such. Next, review the } \\
\text { list of norm-referenced measures below. } \\
\text { Common examples of norm-referenced measures } \\
\text { include IQ tests (WJ-III; WISC; WIAT), and math and } \\
\text { reading achievement measures (TEMA, KeyMath, } \\
\text { SESAT, SAT-10, GORT). Typically, norm-referenced } \\
\text { measures will have a citation along with the } \\
\text { description. } \\
\text { - Researcher-developed = refers to measures that were developed } \\
\text { by the authors of the study for the purpose of the study or were } \\
\text { adapted from previous researcher-developed measures. These } \\
\text { measures tend to be narrower in focus, such as asking a child to } \\
\text { count or identify numerals. Many home numeracy or learning } \\
\text { environment scales are researcher developed. Some researchers } \\
\text { also do not use their own measures, but measures that were } \\
\text { developed by other researchers. Sometimes, these have citations. } \\
\text { Other = use this code if a measure is referred to as something } \\
\text { other than norm-referenced or researcher-developed. }\end{array}$ \\
\hline Page No. & Number & Note the page number where the measure is described in the study. \\
\hline $\begin{array}{l}\text { Measure } \\
\text { Respondent }\end{array}$ & $\begin{array}{l}\text { Select one: } \\
0=\text { not reported } \\
1=\text { child } \\
2 \text { = parent or caregiver } \\
3 \text { = researcher } \\
4=\text { other }\end{array}$ & $\begin{array}{l}\text { This code refers to who responded to the measure or was administered } \\
\text { the measure by a researcher. } \\
\text { - Not reported = it is not reported who the focus of the measure } \\
\text { administration was. } \\
\text { - Child = the child responded to items. } \\
\text { - Parent or caregiver = the parent or caregiver responded to items. } \\
\text { - Researcher = the researcher observed child or parent behavior } \\
\text { (e.g., used a checklist to observe math talk) and recorded data. }\end{array}$ \\
\hline
\end{tabular}




\begin{tabular}{|c|c|c|}
\hline & & $\begin{array}{l}\text { - Other }=\text { another adult or sibling responded to items or multiple } \\
\text { respondents }\end{array}$ \\
\hline Measure Content & $\begin{array}{l}\text { Select one: } \\
0=\text { unclear } \\
1=\text { math achievement } \\
2=\text { math talk } \\
3=\text { reading or literacy } \\
4=\text { home math survey } \\
5=\text { home literacy } \\
\text { survey } \\
6=\text { home learning } \\
\text { environment } \\
7=\text { math attitude, } \\
\text { beliefs, perceptions } \\
8=\text { executive function } \\
9=1 Q \text { test or cognitive } \\
\text { measure } \\
10=\text { other }\end{array}$ & $\begin{array}{l}\text { This code refers to the main content or domain of the measure. } \\
\text { - Unclear = Use this code if authors were unclear in the type of } \\
\text { content or skill that the measure assessed. } \\
\text { Math achievement = Use this code for all math knowledge and } \\
\text { skills measures including, but not limited to, counting, early } \\
\text { numeracy, number identification, computation, concepts and } \\
\text { applications, problem solving, story problems, WJ-III Calculation, } \\
\text { WJ-III Applied Problems, KeyMath, TEMA, TOMA, Aimsweb. This } \\
\text { does not refer to IQ tests of ABILITY (WJ is an IQ test, but the } \\
\text { achievement subtests are still achievement measures - calculation } \\
\text { and applied problems) } \\
\text { - Math talk = use this code for all measures of "math talk" such as } \\
\text { frequency of words or utterances spoken, or type of math words } \\
\text { spoken. } \\
\text { Reading or literacy = use this code for all measures that are related } \\
\text { to reading achievement or other areas of literacy (e.g., } \\
\text { phonological awareness, reading comprehension, letter } \\
\text { identification, vocabulary). } \\
\text { Home math environment = use this code if parents responded to a } \\
\text { survey, interview, open ended questionnaire, etc. about the home } \\
\text { numeracy environment or home math environment. If there is a } \\
\text { separate home literacy/reading environment scale, that should go } \\
\text { on its own line in Excel. } \\
\text { Home literacy environment = use this code if parents responded to } \\
\text { a survey, interview, open ended questionnaire, etc. about the } \\
\text { home literacy environment or home reading environment. If } \\
\text { there is a separate home math/numeracy environment scale, that } \\
\text { should go on its own line in Excel. }\end{array}$ \\
\hline
\end{tabular}




\begin{tabular}{|c|c|c|}
\hline & & $\begin{array}{l}\text { - Home learning environment = use this code if parents responded } \\
\text { to a survey, interview, open ended questionnaire, etc. about the } \\
\text { home learning environment generally; this may refer to one } \\
\text { survey that captured both reading and math information. If } \\
\text { separate measures are used, you should put both measures on } \\
\text { their own lines in Excel. } \\
\text { - Math perceptions, beliefs, attitude = this refers to any measure } \\
\text { that captures a child or parents' beliefs about math, attitude or } \\
\text { enjoyment related to math, self-efficacy in performing math tasks, } \\
\text { beliefs about the importance of academics, etc. } \\
\text { - Executive function = tests related to executive function skills } \\
\text { including attention, inhibitory control, updating working memory, } \\
\text { cognitive flexibility or shifting. There are several different names } \\
\text { for EF measures, but they should be referred to as an EF measure. } \\
\text { - IQ tests of ability (WJ ability measure, WISC, WIAT, etc.) } \\
\text { - Other = this refers to any other measure not listed above } \\
\text { O If there is an "ANS" measure, it should be coded as "other" } \\
\text { here. } \\
\text { O If there is a treatment fidelity measure (e.g., parent survey } \\
\text { documenting intervention participation), code "other" } \\
\text { here. }\end{array}$ \\
\hline $\begin{array}{l}\text { Other Content Area } \\
\text { Note }\end{array}$ & Anecdotal or NA & $\begin{array}{l}\text { - Use NA when you did not select "Other "for the Measure Content } \\
\text { - If you did select "Other," report the content area, skill, or domain } \\
\text { that the measure focused on. }\end{array}$ \\
\hline $\begin{array}{l}\text { Home Numeracy or } \\
\text { Environment Scale } \\
\text { Questions Reported }\end{array}$ & $\begin{array}{l}\text { Select one: } \\
0=\text { not applicable } \\
1=\text { no, questions are } \\
\text { not reported } \\
2=\text { yes, questions } \\
\text { reported }\end{array}$ & $\begin{array}{l}\text { This item directly relates to the Measure Content code above, specifically } \\
\text { home numeracy or home math environment scales and/or } \\
\text { questionnaires. Were the specific questions related to the home } \\
\text { environment provided in the study? }\end{array}$ \\
\hline
\end{tabular}




\begin{tabular}{|c|c|c|}
\hline & & $\begin{array}{l}\text { - Not applicable = select this option if the study did not collect data } \\
\text { related to the home numeracy or home math environment (i.e. } \\
\text { you did not pick 4, 5, or } 6 \text { for the "measure content" code above) } \\
\text { - Not reported = The authors collected data related to the home } \\
\text { math or numeracy environment, BUT the specific questions asked } \\
\text { were not provided. } \\
\text { - Yes reported = The authors collected data related to the home } \\
\text { math or numeracy environment, AND the specific questions asked } \\
\text { were provided. }\end{array}$ \\
\hline $\begin{array}{l}\text { Math Achievement } \\
\text { Measures } \\
\text { Description (for } \\
\text { meta-analysis } \\
\text { studies only) }\end{array}$ & Anecdotal or NA & $\begin{array}{l}\text { For math achievement measures only (and for meta-analysis only), } \\
\text { provide a short list of skills included in the measure. Simply report the } \\
\text { skills that are reported in the study. For example, for a measure called } \\
\text { "counting" you might write "students asked to count as high as possible } \\
\text { without making a mistake" or for larger tests you might report "subtest } \\
\text { included items about counting, comparison, measurement, and calendar } \\
\text { activities." } \\
\text { - If the measure was not math achievement measures and/or is not } \\
\text { for the meta-analysis, code "NA" here. In other words, only } \\
\text { include an anecdotal code here if you selected "1=meta" for the } \\
\text { meta/quality code above and "1=math achievement" for the } \\
\text { measure content code above. }\end{array}$ \\
\hline $\begin{array}{l}\text { Time Measure Was } \\
\text { Administered }\end{array}$ & $\begin{array}{l}\text { Select one: } \\
0=\text { not reported } \\
1=\text { pretest only } \\
2=\text { posttest only } \\
3=\text { pretest and } \\
\text { posttest } \\
4=\text { posttest and } \\
\text { delayed posttest } \\
5=\text { pretest, posttest, } \\
\text { and delayed posttest }\end{array}$ & $\begin{array}{l}\text { This code refers to when the measure was administered. } \\
\text { - Not reported = the authors do not state anything about when the } \\
\text { measure was administered. } \\
\text { - Pretest only = the measure was collected/administered at only } \\
\text { one point in time, which was right before the intervention began. } \\
\text { - Posttest only = the measure was collected/administered at only } \\
\text { one point in time, which was after the intervention. } \\
\text { - Pretest and posttest = the measure was collected/administered } \\
\text { both before and after the intervention. }\end{array}$ \\
\hline
\end{tabular}




\begin{tabular}{|c|c|c|}
\hline & $6=$ Other & $\begin{array}{l}\text { - Posttest and delayed posttest = the measure was } \\
\text { collected/administered both after the intervention and at a later } \\
\text { follow-up session. } \\
\text { - Pretest, posttest, and delayed posttest = the measure was } \\
\text { collected/administered before, after, and at a later follow up } \\
\text { session. } \\
\text { - Other = the measure was administered using a different schedule } \\
\text { than listed. } \\
\text { o If the measure was administered "well before" (e.g., } \\
\text { several weeks) before the intervention began, code } \\
\text { "other" here. }\end{array}$ \\
\hline $\begin{array}{l}\text { Administration Time } \\
\text { Other Note }\end{array}$ & Anecdotal or NA & $\begin{array}{l}\text { - If you selected codes 0-5 in the "Time Measure was Administered" } \\
\text { - If you selected a code of Other above, include a note about the } \\
\text { administration time. }\end{array}$ \\
\hline $\begin{array}{l}\text { Posttest } \\
\text { Administration Time }\end{array}$ & $\begin{array}{l}\text { Select one: } \\
0=\text { not applicable } \\
1=\text { not reported } \\
2=\text { administered } \\
\text { within } 2 \text { weeks of } \\
\text { intervention } \\
3=\text { administered more } \\
\text { than } 2 \text { weeks after } \\
\text { intervention } \\
4=\text { administered } \\
\text { "immediately" with no } \\
\text { specifics provided }\end{array}$ & $\begin{array}{l}\text { This code refers to whether the posttest (if administered) was given } \\
\text { "immediately," or within } 2 \text { weeks of the intervention ending. It is } \\
\text { appropriate to make inferences here. For example, if the intervention was } \\
\text { only five minutes in a museum, if the author says the posttest was given } \\
\text { immediately after the intervention, we can assume it was given within } \\
\text { two weeks. } \\
\text { - Not applicable = the measure was not given at posttest. } \\
\text { - Not reported = the measure was given at posttest, but the authors } \\
\text { - did not state when posttest measures were administered. } \\
\text { that the measure was given no more than } 2 \text { weeks after the end of } \\
\text { the intervention (for all students), or that the posttest sessions } \\
\text { occurred immediately after intervention. } \\
\text { - Administered more than } 2 \text { weeks after intervention = the authors } \\
\text { state that the posttest was given more than } 2 \text { weeks after the } \\
\text { intervention; this includes statements such as "posttest was given }\end{array}$ \\
\hline
\end{tabular}




\begin{tabular}{|c|c|c|}
\hline & & $\begin{array}{l}\text { right after the intervention ended and testing took approximately } \\
3 \text { weeks to complete for all children." } \\
\text { - Administered "immediately" with no specifics provided: The } \\
\text { authors state that the post test was given "immediately after," } \\
\text { "shortly after," etc. the invention. However, no specific } \\
\text { information (e.g., number of days) was provided. }\end{array}$ \\
\hline $\begin{array}{l}\text { Posttest } \\
\text { Administration Time } \\
\text { Information }\end{array}$ & Anecdotal or NA or NR & $\begin{array}{l}\text { - Include only the number and the unit (e.g., } 1 \text { week) } \\
\text { O Record the number of days, weeks, or months after the } \\
\text { end of the intervention that the post-test was } \\
\text { administered. } \\
\text { O Include the unit (days, weeks, months). } \\
\text { - Not applicable = the measure was not given at posttest. } \\
\text { - Not reported = the measure was given at posttest, but the authors } \\
\text { did not state when posttest measures were administered. }\end{array}$ \\
\hline Number of Items & Number or NR & $\begin{array}{l}\text { - Report the number of items in the measure/assessment. } \\
\text { - Do not include any practice items in your total. } \\
\text { - It is acceptable to figure out the number of items, if possible, } \\
\text { when the author doesn't explicitly state how many items the } \\
\text { measure has } \\
\text { O For measures that are scales, surveys, or interviews, check } \\
\text { the tables presented in the study to determine if the items } \\
\text { are presented in the results (e.g., authors may put all items } \\
\text { from the measure in a results table). } \\
\text { Also, if the measure is included in the article, you can count the items. } \\
\text { Be sure to check the appendix or supplementary } \\
\text { resources for the measures. }\end{array}$ \\
\hline $\begin{array}{l}\text { Reliability Type } \\
\text { Reported }\end{array}$ & $\begin{array}{l}0=\text { not reported } \\
1=\text { reported for each } \\
\text { of the following } \\
\text { reliability types: }\end{array}$ & $\begin{array}{l}\text { This code refers to the type of reliability that is reported for each } \\
\text { measure. For each type of reliability, you will code either " } 0 \text { " or " } 1 \text { " in } \\
\text { your spreadsheet. For example, if the study has test retest and split half, } \\
\text { you code " } 1 \text { " for both of those and " } 0 \text { " for everything else. To receive a }\end{array}$ \\
\hline
\end{tabular}




\begin{tabular}{|c|c|c|}
\hline & $\begin{array}{l}\text { - } \text { internal } \\
\text { reliability, } \\
\text { consistency; } \\
\text { Cronbach's } \\
\text { alpha } \\
\text { - } \text { test retest } \\
\text { - } \text { parallel form } \\
\text { - } \text { split half } \\
\text { - interrater } \\
\text { - } \text { other }\end{array}$ & $\begin{array}{l}\text { code of } 1 \text {, the reliability estimate (the numeral) must be given. For } \\
\text { example, (.89 or }>.90) \text {; authors that reported "internal reliability was } \\
\text { good/acceptable/moderate/etc." would not receive credit for this item. } \\
\text { - Not reported = the authors did not report any reliability estimates } \\
\text { for the measure. } \\
\text { - Internal consistency; internal reliability; Cronbach's alpha = the } \\
\text { authors reported reliability across items within the measure. } \\
\text { - Test retest = the correlation between one test administration and } \\
\text { another test administration of the same measure is provided. } \\
\text { - Parallel form = reliability between multiple (two or more) versions } \\
\text { of the same test (sometimes called Form A, B) is provided. This is } \\
\text { sometimes called an alternate form. } \\
\text { - Split half = reliability of one half of the test compared to the other } \\
\text { - half of the test is provided. } \\
\text { Interrater agreement = reliability of scores across different raters } \\
\text { is provided for the specific measure (if it is provided as an } \\
\text { aggregate across all measures do not select this; See Item XX). } \\
\text { Other = any other type of reliability information provided. }\end{array}$ \\
\hline Reliability: Other & Anecdotal or NA & $\begin{array}{l}\text { Use NA if you did not select the code of "Other" above. If you selected a } \\
\text { code of "other" for reliability, describe the type of reliability. }\end{array}$ \\
\hline Reliability Source & $\begin{array}{l}\text { Select one: } \\
0=\text { NA } \\
1=\text { sample } \\
2=\text { publisher } \\
3=\text { sample and } \\
\text { publisher }\end{array}$ & $\begin{array}{l}\text { This code refers to whether the information about reliability, collectively, } \\
\text { was captured from the sample in the study or if it was reported from the } \\
\text { test manual or publisher. If the reliability is reported for the sample, it will } \\
\text { usually be for internal consistency; internal reliability; Cronbach's alpha. } \\
\text { - Not applicable = you selected a code of "not reported" above for } \\
\text { all types of reliability and reliability was not reported for the } \\
\text { measure } \\
\text { - Sample = the reliability for the measure was based on the current } \\
\text { study's sample (the manuscript will report this by referring to the } \\
\text { sample) }\end{array}$ \\
\hline
\end{tabular}




\begin{tabular}{|c|c|c|}
\hline & & $\begin{array}{l}\text { - Publisher = the reliability for the measure is reported by the } \\
\text { authors as referring to the publisher or test manual for that } \\
\text { measure. Examples include "as reported by Jordan et al. (2009) } \\
\text { the test-retest reliability is .89" or "as reported in the test manual } \\
\text { internal consistency is .90." } \\
\text { - Sample and publisher = both sources of reliability are provided }\end{array}$ \\
\hline Validity Reported & $\begin{array}{l}\text { Select one: } \\
0=\text { not reported } \\
1=\text { construct validity } \\
2=\text { content validity } \\
3=\text { expert validity } \\
4=\text { criterion validity } \\
\text { (concurrent or } \\
\text { predictive validity) } \\
5=\text { more than one type } \\
6=\text { other }\end{array}$ & $\begin{array}{l}\text { This code refers to whether information about the validity of the measure } \\
\text { was reported. To this study, a few types of validity are likely to be } \\
\text { reported (1. expert concurrent; } 2 \text {. or concurrent or predictive). Validity } \\
\text { refers to how well the measure measured the construct that was } \\
\text { intended to be measured. } \\
\text { - Not reported = no information about validity was reported. } \\
\text { - Construct = does the test measure what it is intended to measure. } \\
\text { To code a yes for this, the author can simply say that the measure } \\
\text { had construct validity and not report a statistic. } \\
\text { - Content = does the test measure the full construct or is it } \\
\text { representative of the whole construct. To code a yes for this, the } \\
\text { author can simply say that the measure had construct validity and } \\
\text { not report a statistic. } \\
\text { - Expert validity = did the authors report that validity of the } \\
\text { measure was established by using experts to design the measure? } \\
\text { Criterion validity = how well the test relates to another measure. } \\
\text { This is sometimes referred to as Concurrent or predictive validity= } \\
\text { did the authors report how the measure correlated ( } r \text { ) with } \\
\text { student performance on another measure? NOTE: Concurrent and } \\
\text { predictive validity may be reported as correlations in the Results, } \\
\text { especially for researcher-developed measures, as opposed to in } \\
\text { the Method. To receive a code of } 1 \text { for this, the authors can simply } \\
\text { report that there is criterion, predictive, or concurrent validity } \\
\text { without reporting a statistic. }\end{array}$ \\
\hline
\end{tabular}




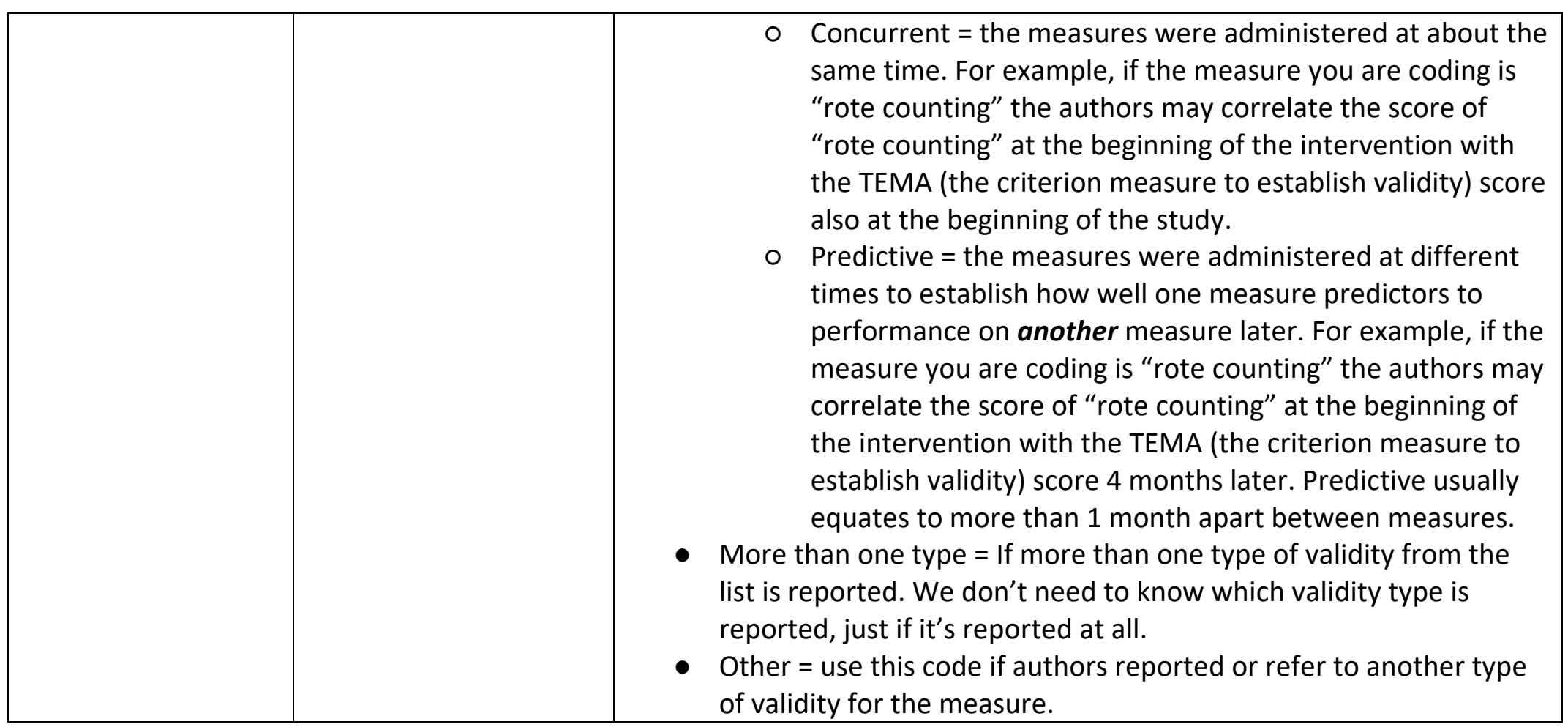

\section{Quality of Results at the Study Level}

\begin{tabular}{|l|l|l|}
\hline Variable Name & Code Options & Code Descriptions \\
\hline $\begin{array}{l}\text { Quality: Data } \\
\text { Analysis Part 1 }\end{array}$ & $\begin{array}{l}\text { Select one: } \\
0=\text { no } \\
1=\text { yes }\end{array}$ & $\begin{array}{l}\text { "Were the data analysis techniques appropriately linked to key research } \\
\text { questions and hypotheses? (Gersten, 2005; p.152)" } \\
\text { Was the data analysis plan or technique reported? In other words, did the } \\
\text { authors provide a description of their analyses? } \\
\text { Record: Yes or No (If you record "no" also make a small note about the } \\
\text { rationale) }\end{array}$ \\
\hline
\end{tabular}




\begin{tabular}{|l|l|l|}
\hline $\begin{array}{l}\text { Quality: Data } \\
\text { Analysis Part } 2\end{array}$ & $\begin{array}{l}\text { Select one: } \\
0=\text { no } \\
1=\text { yes }\end{array}$ & $\begin{array}{l}\text { "Were the data analysis techniques appropriately linked to key research } \\
\text { questions and hypotheses? (Gersten, 2005; p.152)" } \\
\text { Record: Yes or No (If you record "no" also make a small note about the } \\
\text { rationale) }\end{array}$ \\
\hline $\begin{array}{l}\text { Quality of Data } \\
\text { Analysis: Part } 3\end{array}$ & $\begin{array}{l}\text { Select one: } \\
0=\text { no } \\
1=\text { yes }\end{array}$ & $\begin{array}{l}\text { Quality of Data Analysis: Part } 3 \\
\text { "Were the data analysis techniques appropriately linked to the unit of } \\
\text { analysis in the study? (Gersten, 2005; p.152)" } \\
\text { Record: Yes or No (If you record "no" also make a small note about the } \\
\text { rationale) }\end{array}$ \\
\hline $\begin{array}{l}\text { Quality of Reporting } \\
\text { Results }\end{array}$ & $\begin{array}{l}\text { Select one: } \\
0=\text { no } \\
1=\text { yes }\end{array}$ & $\begin{array}{l}\text { "Were results presented in a clear, coherent fashion? (Gersten, 2005; } \\
\text { p.152) }\end{array}$ \\
\hline
\end{tabular}

\section{Effect Size Level Information}

\begin{tabular}{|l|l|l|}
\hline Variable Name & Code Options & Code Descriptions \\
\hline $\begin{array}{l}\text { Number of } \\
\text { achievement } \\
\text { measures }\end{array}$ & Anecdotal & $\begin{array}{l}\text { How many math achievement measures were administered in this study } \\
\text { that allow for effect size calculation? }\end{array}$ \\
\hline Specific Outcome & Title of assessment & $\begin{array}{l}\text { What outcome measure is this effect size associated with? (Record the } \\
\text { name of the measure as it appears in the study) }\end{array}$ \\
\hline $\begin{array}{l}\text { Quality of Effect Size } \\
\text { Reporting }\end{array}$ & $\begin{array}{l}\text { Select one: } \\
0=\text { no } \\
1=\text { yes }\end{array}$ & $\begin{array}{l}\text { Did the study report the effect size calculations for this outcome measure } \\
\text { in a manner that demonstrates the effectiveness of the intervention? }\end{array}$ \\
\hline $\begin{array}{l}\text { Design associated } \\
\text { with the effect size }\end{array}$ & Select one: & Select the administration that represents the effect size. \\
\hline
\end{tabular}




\begin{tabular}{|c|c|c|}
\hline & $\begin{array}{ll}\text { - } & \text { Single Group } \\
\text { (Pretest/Posttest) } \\
\text { - Independent } \\
\text { Groups } \\
\text { (Pretest/Posttest) } \\
\text { - Independent } \\
\text { Groups (Posttest } \\
\text { only) }\end{array}$ & \\
\hline Group Name & Anecdotal & $\begin{array}{l}\text { What group (if there is more than one treatment group or control group) } \\
\text { is this effect size information associated with? }\end{array}$ \\
\hline $\begin{array}{l}\text { Pre-test sample size } \\
\text { treatment }\end{array}$ & Number & Record the pre-test sample size for the treatment group \\
\hline $\begin{array}{l}\text { Pre-test sample size } \\
\text { comparison }\end{array}$ & Number & Record the pre-test sample size for the comparison group \\
\hline $\begin{array}{l}\text { Post-test sample size } \\
\text { treatment }\end{array}$ & Number & Record the post-test sample size for the treatment group \\
\hline $\begin{array}{l}\text { Post-test sample size } \\
\text { comparison }\end{array}$ & Number & Record the post-test sample size for the comparison group \\
\hline $\begin{array}{l}\text { Pre-test Mean } \\
\text { treatment }\end{array}$ & Number & Record the pre-test Mean on the math outcome for the treatment group \\
\hline $\begin{array}{l}\text { Pre-test SD } \\
\text { treatment }\end{array}$ & Number & Record the pre-test SD on the math outcome for the treatment group \\
\hline $\begin{array}{l}\text { Pre-test Mean } \\
\text { comparison }\end{array}$ & Number & Record the pre-test Mean on the math outcome for the comparison group \\
\hline
\end{tabular}




\begin{tabular}{|c|c|c|}
\hline $\begin{array}{l}\text { Pre-test SD } \\
\text { comparison }\end{array}$ & Number & Record the pre-test SD on the math outcome for the comparison group \\
\hline $\begin{array}{l}\text { Post-test Mean } \\
\text { treatment }\end{array}$ & Number & Record the post-test Mean on the math outcome for the treatment group \\
\hline $\begin{array}{l}\text { Post-test SD } \\
\text { treatment }\end{array}$ & Number & Record the post-test SD on the math outcome for the treatment group \\
\hline $\begin{array}{l}\text { Post-test Mean } \\
\text { comparison }\end{array}$ & Number & $\begin{array}{l}\text { Record the post-test Mean on the math outcome for the comparison } \\
\text { group }\end{array}$ \\
\hline $\begin{array}{l}\text { Post-test SD } \\
\text { comparison }\end{array}$ & Number & Record the post-test SD on the math outcome for the comparison group \\
\hline $\begin{array}{l}\text { Adjusted post-test } \\
\text { Mean treatment }\end{array}$ & Number & $\begin{array}{l}\text { Record the adjusted post-test Mean on the math outcome for the } \\
\text { treatment group }\end{array}$ \\
\hline $\begin{array}{l}\text { Adjusted post-test } \\
\text { SD treatment }\end{array}$ & Number & $\begin{array}{l}\text { Record the adjusted post-test SD on the math outcome for the treatment } \\
\text { group }\end{array}$ \\
\hline $\begin{array}{l}\text { Adjusted post-test } \\
\text { Mean comparison }\end{array}$ & Number & $\begin{array}{l}\text { Record the adjusted post-test Mean on the math outcome for the } \\
\text { comparison group }\end{array}$ \\
\hline $\begin{array}{l}\text { Adjusted post-test } \\
\text { SD comparison }\end{array}$ & Number & $\begin{array}{l}\text { Record the adjusted post-test SD on the math outcome for the } \\
\text { comparison group }\end{array}$ \\
\hline $\begin{array}{l}\text { Pre to post } \\
\text { correlation }\end{array}$ & Number & $\begin{array}{l}\text { Record the correlation between pre-test scores and post-test scores on } \\
\text { the outcome measure }\end{array}$ \\
\hline Measure reliability & Number & $\begin{array}{l}\text { Record reliability (Cronbach's alpha if given, or note other kind of } \\
\text { reliability) of the measure }\end{array}$ \\
\hline
\end{tabular}

If Means and SD for pre and post-test scores on the math achievement test are not given, record the following:

Nelson, Carter, Boedeker (2021) 


\begin{tabular}{|l|l|}
\hline Information to Record & Number \\
\hline F-statistic & \\
\hline Degrees of freedom for F-test & \\
\hline$p$-value from F-test & \\
\hline $\begin{array}{l}\text { Independent } t \text {-statistic } \\
\text { (independent samples, “between groups) }\end{array}$ & \\
\hline Degrees of freedom for t-test & \\
\hline$p$-value from t-test & \\
\hline & \\
\hline $\begin{array}{l}\text { Dependent } t \text {-statistic } \\
\text { (within groups”) }\end{array}$ & \\
\hline Degrees of freedom for t-test & \\
\hline$p$-value from t-test & \\
\hline
\end{tabular}

